\title{
The Impact of the Hepatocyte-to-Plasma pH Gradient on the Prediction of Hepatic Clearance and Drug-Drug Interactions for CYP2C9 and CYP3A4 Substrates ${ }^{\text {}}$
}

\author{
Luc R. A. Rougée, Michael A. Mohutsky, David W. Bedwell, Kenneth J. Ruterbories, \\ and Stephen D. Hall
}

Lilly Research Laboratories, Eli Lilly and Company, Indianapolis, Indiana

Received April 17, 2017; accepted June 26, 2017

\begin{abstract}
Surrogate assays for drug metabolism and inhibition are traditionally performed in buffer systems at $\mathrm{pH} 7.4$, despite evidence that hepatocyte intracellular $\mathrm{pH}$ is 7.0 . This $\mathrm{pH}$ gradient can result in a $\mathrm{pK}_{\mathrm{a}}$-dependent change in intracellular/extracellular concentrations for ionizable drugs that could affect predictions of clearance and P450 inhibition. The effect of microsomal incubation $\mathrm{pH}$ on in vitro enzyme kinetic parameters for CYP2C9 (diclofenac, (S)-warfarin) and CYP3A4 (midazolam, dextromethorphan, testosterone) substrates, enzyme specific reversible inhibitors (amiodarone, desethylamiodarone, clozapine, nicardipine, fluconazole, fluvoxamine, itraconazole) and a mechanism-based inhibitor (amiodarone) was investigated. Intrinsic clearance through CYP2C9 significantly increased $(25 \%$ and $50 \%$ for diclofenac and (S)-warfarin respectively) at intracellular pH $7.0 \mathrm{com}$ pared with traditional pH 7.4. The CYP3A4 substrate dextromethorphan intrinsic clearance was decreased by $320 \%$ at $\mathrm{pH} 7.0$, while midazolam
\end{abstract}

and testosterone remained unchanged. Reversible inhibition of CYP2C9 was less potent at $\mathrm{pH} 7.0$ compared with 7.4 , while CYP3A4 inhibition potency was variably affected. Maximum enzyme inactivation rate of amiodarone toward CYP2C9 and CYP3A4 decreased at $\mathrm{pH}$ 7.0, while the irreversible inhibition constant remained unchanged for CYP2C9, but decreased for CYP3A4 at pH 7.0. Predictions of clearance and drug-drug interactions made through physiologically based pharmacokinetic models were improved with the inclusion of predicted intracellular concentrations based at $\mathrm{pH} 7.0$ and in vitro parameters determined at $\mathrm{pH}$ 7.0. No general conclusion on the impact of $\mathrm{pH}$ could be made and therefore a recommendation to change buffer $\mathrm{pH}$ to 7.0 cannot be made at this time. It is recommended that the appropriate hepatocyte intracellular $\mathrm{pH} 7.0$ be used for in vitro determinations when in vivo predictions are made.

\section{Introduction}

The quantification of drug intrinsic clearance and inhibition potency of cytochrome $\mathrm{P} 450$ (P450) enzymes is commonly performed with the human liver microsomes (HLM) and hepatocytes in buffer systems at $\mathrm{pH}$ 7.4 (Pelkonen et al., 2005; Zhang et al., 2012). Hepatocytes have been shown to provide improved predictions of in vivo clearance and inhibition potential compared with HLM (Lu et al., 2006; Chiba et al., 2009). This difference in predictive accuracy may reflect the arbitrary choice of microsomal incubation conditions, such as buffer constituents, ionic strength, and $\mathrm{pH}$, commonly employed to facilitate the quantitation of enzyme parameters (London et al., 1975; Brooks et al., 2012). Microsomal incubations are generally conducted at $\mathrm{pH} 7.4$ despite the fact that the $\mathrm{pH}$ of the cytosol and the endoplasmic reticulum of hepatocytes, where many drug metabolizing enzymes are located, has been shown to be 7.0 (Pollock, 1984; Strazzabosco et al., 1995; Kim et al., 1998; Hall and Guyton, 2015).

As a result of the $\mathrm{pH}$ differential between the intracellular hepatocyte environment $(\mathrm{pH} 7.0)$ and the surrounding plasma $(\mathrm{pH} 7.4)$, a $\mathrm{pK}_{\mathrm{a}}$ dependent ratio of intracellular unbound to the plasma unbound drug

https://doi.org/10.1124/dmd.117.076331.

SThis article has supplemental material available at dmd.aspetjournals.org. concentration ( $\left.\mathrm{Kp}_{\mathrm{uu}}\right)$ exists (Shore et al., 1957; Mateus et al., 2013; Hall and Guyton, 2015). An ionization factor $\left(\mathrm{F}_{\mathrm{I}}\right)$, based on the HendersonHasselbalch equation has been employed to correct hepatic clearance models and whole body distribution models for the difference between unbound plasma concentration and unbound intracellular drug concentrations (Berezhkovskiy, 2011; Poulin et al., 2012a,b; Poulin and Haddad, 2013). Application of the $F_{I}$ correction rests on three assumptions: 1) the drug is not subject to active transport, 2) the total unbound concentration and not a particular species (ionized or un-ionized) determines the rate of association between drug and enzyme, and 3) in vitro determinations of the Michaelis-Menten constant $\left(\mathrm{K}_{\mathrm{m}}\right)$, maximum rate of reaction $\left(\mathrm{V}_{\max }\right)$, intrinsic clearance $\left(\mathrm{CL}_{\text {int }}\right)$ and fraction unbound generated at the traditional $\mathrm{pH} 7.4$ can be used as there is no significant difference with data generated at $\mathrm{pH} 7.0$ (Berezhkovskiy et al., 2012).

These assumptions were evaluated using HLM to investigate the impact of $\mathrm{pH}$ on the major drug-metabolizing enzyme CYP2D6 through metabolism of prototypical probe substrates, bufuralol and dextromethorphan (Rougée et al., 2016). The study found no indication that a particular species, ionized or un-ionized, of substrate was responsible for changes in CYP2D6 kinetic parameters $\left(\mathrm{K}_{\mathrm{m}}, \mathrm{V}_{\max }, \mathrm{CL}_{\text {int }}\right)$. Although this suggests that the total concentration of drug drives the reaction for CYP2D6, this conclusion was uncertain as the ionized states of both the

ABBREVIATIONS: AUC, area under the plasma concentration-time curve; DDI, drug-drug interactions; $\mathrm{F}_{1}$, ionization factor; HLM, human liver microsomes; IVIVE, in vitro to in vivo extrapolation; PBPK, physiologically-based pharmacokinetic; PK, pharmacokinetic; P450, cytochrome P450; TDI, time-dependent inhibition. 
enzyme and the drug change with $\mathrm{pH}$, making it difficult to discern a relationship. However, the study observed that in vitro data generated at pH 7.0 was significantly different (outside of assay variability) when compared with data generated at the traditional $\mathrm{pH} 7.4$ condition (Rougée et al., 2016). In the model, the $F_{I}$ correction resulted, for these basic compounds, in an increase in hepatocyte intracellular drug concentration. However, this increase was offset by an inverse decrease in enzyme clearance for the enzyme/substrate combinations studied. A similar observation was made for the inhibitor quinidine, whereby the decrease in inhibitor potency at $\mathrm{pH} 7.0$ was compensated by the $\mathrm{F}_{\mathrm{I}}$ corrected intracellular concentration. While these patterns emerged for CYP2D6, no general conclusion on the influence of $\mathrm{pH}$ could be extended to other P450 enzymes.

The objective of the current study was to expand the investigation of the influence of $\mathrm{pH}$ to the major drug metabolizing enzymes CYP2C9 and CYP3A4. Using HLM, enzyme kinetic parameters $\left(\mathrm{K}_{\mathrm{m}}\right.$, $\mathrm{V}_{\max }$ and $\mathrm{CL}_{\text {int }}$ ) were determined through metabolite formation from substrates diclofenac and (S)-warfarin for CYP2C9, and midazolam, dextromethorphan and testosterone for CYP3A4. Changes in fraction unbound in microsomes $\left(\mathrm{fu}_{\mathrm{mic}}\right)$, as well as reversible and timedependent inhibition constants of inhibitors toward these substrates were also investigated. The in vitro findings at intracellular $\mathrm{pH} 7.0$ and traditional assay $\mathrm{pH} 7.4$ were used to inform physiologically based pharmacokinetic (PBPK) models to predict exposure and drug-drug interactions (DDIs). The $\mathrm{F}_{\mathrm{I}}$ correction was used to account for changes in intracellular concentrations in conjunction with $\mathrm{pH}$ adjusted kinetic parameters in an attempt to establish general trends for P450 enzymes.

\section{Materials and Methods}

Materials. Chemical reagents were obtained commercially: amiodarone, clozapine, dextromethorphan, diclofenac, fluconazole, NADPH, nicardipine, testosterone, 3-methoxymorphinan (Sigma Aldrich Ltd., St. Louis, MO); 1'hydroxymidazolam, midazolam, 4'-hydroxydiclofenac, $6 \beta$-hydroxytestosterone (Cerilliant, Round Rock, TX); (S)-warfarin (Cayman Chemicals, Ann Arbor, MI); desethylamiodarone, itraconazole, (S)-7-hydroxywarfarin (Toronto Research Chemicals Inc., Toronto, ON, Canada); fluvoxamine, sodium phosphate monobasic, sodium phosphate dibasic, phosphoric acid, and sodium hydroxide (Fisher Scientific, Pittsburgh, PA). A single lot of HLM pooled from 150 individuals (UltraPoolTM, Lot. \#38290, equal proportion male and female; Corning, Tewksbury, MA) was used for all experiments.

In Vitro Incubations. Incubations were carried out in $100 \mathrm{mM}$ sodium phosphate $\left(\mathrm{NaPO}_{4}\right)$ buffers adjusted to $\mathrm{pH}$ of interest $(6.0,6.5,7.0,7.2,7.4,8.0$, $8.5,9.0$ ) with phosphoric acid or sodium hydroxide as necessary in a shaking water bath at $37^{\circ} \mathrm{C}$. Linear conditions for metabolite formation with respect to time and protein at $\mathrm{pH} 6.0, \mathrm{pH} 7.4$, and $\mathrm{pH} 9.0$ were determined for diclofenac, (S)-warfarin, dextromethorphan, testosterone, midazolam, and are reflected in the final conditions described. For each drug investigated, $\mathrm{pH}$ conditions were run side-by-side on the same day to reduce inter-day variability.

Substrates, buffer, and microsomes were premixed, and incubations were initiated by addition of the NADPH cofactor. In the case of reversible inhibition studies, inhibitor and cofactor were added at the initiation of the reaction simultaneously. Time-dependent inhibition studies were performed using the dilution method (Mohutsky and Hall, 2014). All incubations were carried out in 96-well plates in triplicate unless noted otherwise. Product formation (4'-hydroxydiclofenac, (S)-7-hydroxywarfarin, 3-methoxymorphinan, $6 \beta$-hydroxytestosterone, $1^{\prime}$-hydroxymidazolam) assays were performed on three separate occasions. Methanol $(\mathrm{MeOH})$ was used as a solvent for all experiments, unless specified in the methods, with a final percent of solvent in the reaction less than or equal to $2 \% \mathrm{v} / \mathrm{v}$.

CYP2C9 Enzyme Kinetics. The enzyme kinetic parameters for CYP2C9 within the HLM system were determined using the formation of metabolites 4'hydroxydiclofenac and (S)-7-hydroxywarfarin from substrates diclofenac (0.39$50 \mu \mathrm{M})$ and (S)-warfarin $(0.39-50 \mu \mathrm{M})$ using 0.1 and $0.25 \mathrm{mg} / \mathrm{ml}$ HLM respectively in $100 \mathrm{mM} \mathrm{NaPO}_{4}$ buffer over the range of $\mathrm{pH}$ values between 6.0 and 9.0. The mixtures were pre-incubated for 3 minutes at $37^{\circ} \mathrm{C}$ prior to reaction initiation through the addition of NADPH $(1 \mathrm{mM}$, prepared in corresponding $\mathrm{pH}$ buffer), for a total volume of $150 \mu$. The reaction was allowed to proceed at $37^{\circ} \mathrm{C}$ for 10 and 40 minutes for diclofenac and (S)-warfarin respectively, after which a $50 \mu \mathrm{l}$ aliquot was added to $100 \mu \mathrm{l}$ of 90:10 (v/v) MeOH: $\mathrm{H}_{2} \mathrm{O}$ containing internal standard to stop the reaction. Plates were sealed with Easy Pierce $20 \mu \mathrm{m}$ foil (Thermo Fisher Scientific; Waltham, MA), vortexed for 20 second, centrifuged (3500 $g$ for 10 minutes) and analyzed by liquid chromatography-tandem mass spectrometry (LC-MS/MS) (Supplemental Materials, Table S1). Reactions were performed in triplicate wells on three separate occasions. Metabolite formation was determined using a standard curve of the metabolites generated in appropriate concentrations of HLM (4'-hydroxydiclofenac: 1.95-4000 nM and (S)-7hydroxywarfarin: $0.24-500 \mathrm{nM}$ ).

CYP3A4 Enzyme Kinetics. Enzyme kinetic parameters of CYP3A4 within the HLM system were determined by monitoring metabolite formation of 3-methoxymorphinan, $6 \beta$-hydroxytestosterone, and 1'-hydroxymidazolam from the substrates dextromethorphan, testosterone and midazolam respectively. The same procedure as described above for CYP2 $\mathrm{C} 9$ was performed with the following changes: dextromethorphan (23.44-3000 $\mu \mathrm{M} ; 0.1 \mathrm{mg} / \mathrm{ml} \mathrm{HLM})$, testosterone $(1.95-250 \mu \mathrm{M} ; 0.05 \mathrm{mg} / \mathrm{ml})$ and midazolam $(0.23-30 \mu \mathrm{M} ; 0.05 \mathrm{mg} / \mathrm{ml})$ in $100 \mathrm{mM} \mathrm{NaPO}$ buffer at $\mathrm{pH}(6.0-9.0)$ were used; after pre-incubation and initiation, reactions proceeded for 20,5 , and 4 minutes respectively at $37^{\circ} \mathrm{C}$ before being stopped. Metabolite formation was determined using a standard curve of the metabolites generated under identical conditions (3-methoxymorphinan: $1.95-4000 \mathrm{nM} ; 6 \beta$-hydroxytestosterone: $1.95-4000 \mathrm{nM} ; 1$ '-hydroxymidazolam: $0.44-900 \mathrm{nM})$

Inhibitor Enzyme Kinetics. The enzyme kinetic parameters $\left(K_{m}\right.$ and $\left.V_{\max }\right)$ of the inhibitors selected for the DDI simulations were determined in duplicate using the substrate depletion method previously described (Mohutsky et al., 2006). Amiodarone (0.10-200 $\mu \mathrm{M} ; 0.25 \mathrm{mg} / \mathrm{ml} \mathrm{HLM})$, clozapine $(0.24-500 \mu \mathrm{M}$; $0.5 \mathrm{mg} / \mathrm{ml} \mathrm{HLM})$ and itraconazole $(0.00098-1 \mu \mathrm{M}$ dissolved in DMSO; $0.1 \mathrm{mg} / \mathrm{ml} \mathrm{HLM}$ ) prepared in $100 \mathrm{mM} \mathrm{NaPO}_{4}$ buffer at $\mathrm{pH} 7.0$ or $\mathrm{pH} 7.4$ were pre-incubated at $37^{\circ} \mathrm{C}$ for 3 minutes prior to reaction initiation with NADPH ( $1 \mathrm{mM}$, prepared in corresponding $\mathrm{pH}$ buffer), for a total reaction volume of $600 \mu \mathrm{l}$. Reaction aliquots $(50 \mu \mathrm{l})$ were taken at $0,5,10,15,20,30,45,60$ minutes for amiodarone and clozapine, and $0,1,2.5,5,10,15,20,30$ minutes for itraconazole, then added to $200 \mu \mathrm{l}$ of $90: 10(\mathrm{v} / \mathrm{v}) \mathrm{MeOH}: \mathrm{H}_{2} \mathrm{O}$ containing internal standard to stop the reaction. Plates were sealed with Easy Pierce $20 \mu \mathrm{m}$ foil (Thermo Fisher Scientific), vortexed for 20 second, centrifuged $(3500 \mathrm{~g}$ for 10 minutes) and analyzed by LC-MS/MS (Supplemental Materials, Table S1). The concentration of compound remaining was determined using a standard curve generated under identical conditions (amiodarone: 0.03-400 $\mu \mathrm{M}$; clozapine: 0.08-1000 $\mu \mathrm{M}$; itraconazole: $0.49-2000 \mathrm{nM}$ ).

Reversible Inhibition ( $\mathbf{K}_{\mathbf{i}}$ Determination). The equilibrium inhibition constant $\left(\mathrm{K}_{\mathrm{i}}\right)$ was determined at $\mathrm{pH} 7.0$ and $\mathrm{pH} 7.4$ for reversible inhibitors of CYP2C9 (amiodarone, desethylamiodarone, clozapine, fluconazole, fluvoxamine, nicardipine) and CYP3A4 (amiodarone, desethylamiodarone, fluconazole, fluvoxamine, itraconazole). CYP2C9 inhibition was determined with diclofenac $(1.56,3.13,6.25,25 \mu \mathrm{M})$ and (S)-warfarin $(1.56,3.13,6.25,25 \mu \mathrm{M})$ using 0.1 and $0.25 \mathrm{mg} / \mathrm{ml} \mathrm{HLM} \mathrm{respectively} \mathrm{prepared} \mathrm{in} 100 \mathrm{mM} \mathrm{NaPO}_{4}$ buffer at $\mathrm{pH} 7.0$ or $\mathrm{pH} 7.4$ and kept on ice. After pre-incubation $\left(3\right.$ minutes at $\left.37^{\circ} \mathrm{C}\right)$, inhibitor (amiodarone, desethylamiodarone, clozapine, fluconazole, fluvoxamine $(0-100 \mu \mathrm{M})$ or nicardipine $(0-5 \mu \mathrm{M})$ was added with NADPH $(1 \mathrm{mM}$ prepared in corresponding buffer) and allowed to proceed for 10 and 40 minutes for diclofenac and (S)-warfarin respectively (Fowler and Zhang, 2008). Inhibition of CYP3A4 was determined in the same procedure described above for $\mathrm{CYP} 2 \mathrm{C} 9$ with the following changes: $0.05 \mathrm{mg} / \mathrm{ml}$ HLM were incubated for 4 minutes with victim substrate midazolam $(1,4,12,30 \mu \mathrm{M})$ and inhibitors (amiodarone $(0-200 \mu \mathrm{M})$, desethylamiodarone, fluconazole, fluvoxamine $(0-100 \mu \mathrm{M})$ or itraconazole $(0-1 \mu \mathrm{M})$. Reaction aliquots $(50 \mu \mathrm{l})$ were taken after incubation and added to $100 \mu \mathrm{l}$ of 90:10 (v/v) $\mathrm{MeOH}: \mathrm{H}_{2} \mathrm{O}$ containing internal standard to stop the reaction. Plates were sealed with Easy Pierce $20 \mu \mathrm{m}$ foil (Thermo Fisher Scientific), vortexed for 20 second, centrifuged (3500g for 10 minutes) and analyzed by LC-MS/MS (Supplemental Materials, Table S1).

Time-Dependent Inhibition ( $\mathbf{K}_{\mathbf{I}}$ and $\mathbf{k}_{\text {inact }}$ Determination). The maximum rate of enzyme inhibition $\left(\mathrm{k}_{\text {inact }}\right)$ and inhibitor concentration at which half the maximal rate of inactivation occurs $\left(\mathrm{K}_{\mathrm{I}}\right)$ were determined for amiodarone timedependent inhibition of CYP2C9 and CYP3A4 using the dilution method (Mohutsky and Hall, 2014). Briefly, amiodarone (0-100 and 0-25 $\mu \mathrm{M}$ for 
CYP2C9 and CYP3A4 respectively), was incubated at $37^{\circ} \mathrm{C}$ with pooled HLM $(0.5 \mathrm{mg} / \mathrm{ml})$ and NADPH $(1 \mathrm{mM})$ in $100 \mathrm{mM} \mathrm{NaPO}_{4}$ buffer at pH 7.0 or pH 7.4 for $0,2.5,5,15$ and 30 minutes. After pre-incubation, a 10-fold dilution into a secondary incubation containing $50 \mu \mathrm{M}$ diclofenac or $30 \mu \mathrm{M}$ midazolam with NADPH $(1 \mathrm{mM})$ in corresponding buffer at $\mathrm{pH} 7.0$ or 7.4 was performed. The secondary incubation was allowed to proceed 10 and 4 minutes for diclofenac and midazolam, respectively at $37^{\circ} \mathrm{C}$, after which an aliquot $(50 \mu \mathrm{l})$ was added to $100 \mu \mathrm{l}$ of $90: 10$ (v/v) $\mathrm{MeOH}: \mathrm{H}_{2} \mathrm{O}$ containing internal standard to stop the reaction. Plates were sealed with Easy Pierce $20 \mu \mathrm{m}$ foil (Thermo Fisher Scientific), vortexed for 20 second, centrifuged (3500g for 10 minutes) and analyzed by LC-MS/MS (Supplemental Materials, Table S1).

Fraction Unbound in Microsomes. The fraction unbound in microsomes $\left(\mathrm{fu}_{\mathrm{mic}}\right)$ was determined using a 96-well Micro-Equilibrium Dialysis Device HTD 96 (HTDialysis LLC, Gales Ferry, CT) per the manufacturer's instructions at HLM protein concentrations of $0.25 \mathrm{mg} / \mathrm{ml}$. HLM were prepared in $100 \mathrm{mM}$ $\mathrm{NaPO}_{4}$ buffer at $\mathrm{pH} 7.0$ or $\mathrm{pH} 7.4$ containing $1 \mu \mathrm{M}$ of test drug and $100 \mu \mathrm{l}$ added to one side of the dialysis membrane. The corresponding buffer $(\mathrm{pH} 7.0$ or $\mathrm{pH} 7.4$; $100 \mu \mathrm{l})$ was placed on the opposite side of the dialysis membrane. Samples $(n=$ 6 replicates per day; repeated on three separate runs) were incubated in a shaking incubator $(400 \mathrm{rpm})$ at $37^{\circ} \mathrm{C}$ for 4 hour using regenerated cellulose dialysis membranes (molecular weight cut off 6-8 K). After incubation, aliquots from microsomes and buffer sides were taken and quenched into $100 \mu \mathrm{l}$ of 90:10 (v/v) $\mathrm{MeOH}: \mathrm{H}_{2} \mathrm{O}$ containing internal standards. Plates were sealed with Easy Pierce $20 \mu \mathrm{m}$ foil (Thermo Fisher Scientific), vortexed for 20 second, centrifuged ( $3500 \mathrm{~g}$ for 10 minutes) and analyzed by LC-MS/MS (Supplemental Materials, Table S1).

PBPK Simulations. The population-based PBPK simulator Simcyp (V15; Certara, Princeton, NJ) was used to simulate exposure and DDI for three simulation scenarios (Rougée et al., 2016). Scenarios included: 1) baseline Simcyp compound file $\left.\left(\operatorname{Sim}_{\mathrm{pH}} 7.4\right), 2\right)$ baseline Simcyp compound file with the incorporation of $\mathrm{F}_{\mathrm{I}}$ correction $\left(\mathrm{Sim}_{\mathrm{pH}}\right.$ 7.4, FI $), 3$ ) baseline Simcyp compound file corrected using in vitro results from $\mathrm{pH} 7.0$ and $\mathrm{pH} 7.4$ in the current study to correct baseline compound file $\left(\mathrm{Sim}_{\mathrm{pH}}\right.$ 7.0, $\left.\mathrm{FI}\right)$ (Supplemental Material, PBPK Calculations eq. S1-6). In all cases, with the exception for amiodarone, desethylamiodarone and itraconazole, the available baseline Simcyp file was used as a starting point. It was assumed that all bottom-up data in the Simcyp files and literature sources were generated at $\mathrm{pH} 7.4$, unless noted otherwise. In the case of diclofenac, the enzyme kinetic parameters $\left(\mathrm{K}_{\mathrm{m}}\right.$ and $\left.\mathrm{V}_{\max }\right)$ determined in a recombinant system for conversion of diclofenac to the 4 '-hydroxydiclofenac metabolite was provided. To allow for saturation of $\mathrm{CYP} 2 \mathrm{C} 9$ elimination in the gut wall, the enzyme kinetic parameters were kept separate. The recombinant $\mathrm{V}_{\max }$ for the CYP2C9 isoform was converted to an HLM V $\mathrm{V}_{\max }$ using the relative abundance of the enzyme isoform per milligram of protein from the healthy volunteer population (Supplemental Material, Table S2, Fig. S1A). The baseline Simcyp values for $\mathrm{V}_{\max }$ and $\mathrm{K}_{\mathrm{m}}$ were then adjusted using our own in vitro data to calculate an adjusted enzyme kinetic parameter for the $\mathrm{pH} 7.0$ simulations. For example, the calculation for the adjusted $V_{\max }$ was done using eq. 1, where $\mathrm{V}_{\max }$ Simcyp represents the Simcyp compound file $\mathrm{V}_{\max }$ value:

$$
\text { Simulation } V_{\max } p H 7.0=\left(\frac{V_{\max } \text { in vitro } p H 7.0}{V_{\max \text { in vitro } p H} 7.4}\right) \times\left(V_{\max \text { Simcyp }}\right)
$$

For (S)-warfarin, intrinsic clearance $\left(\mathrm{CL}_{\text {int }}\right)$ values for recombinant CYP2C9 genotype $(* 1 / * 1 ; * 1 / * 2 ; * 1 / * 3 ; * 2 / * 2 ; * 2 / * 3 ; * 3 / * 3)$ conversion of (S)-warfarin to the 7 -hydroxywarfarin were provided. Due to the low abundance of CYP2C9 genotypes in the Caucasian population, less than $12 \%$ and $8 \%$ for the $* 2$ and $* 3$ alleles respectively, and for model simplicity, only the wild type genotype $(* 1 / * 1)$ was used for the model (Miners and Birkett, 1998; Scordo et al., 2001). The $\mathrm{CL}_{\text {int }}$ was converted to unbound intrinsic clearance $\left(\mathrm{CL}_{\mathrm{int}, \mathrm{u}}\right)$ using the fraction unbound in microsomes ( $\mathrm{fu}_{\text {mic }}$ ) provided in the baseline Simcyp file using eq. 2:

$$
C L_{\text {int }, u}=\frac{C L_{\text {int }}}{f u_{\text {mic }}}
$$

This recombinant $\mathrm{CL}_{\text {int,u }}$ was converted to an $\mathrm{HLM} \mathrm{CL}_{\text {int,u }}$ by using the relative abundance of the enzyme in the healthy volunteer population, and then adjusted using our own in vitro data to calculate an adjusted $\mathrm{HLM} \mathrm{CL}_{\text {int,u }}$ for the $\mathrm{pH} 7.0$ simulations (Supplemental Material, Table S2, Fig. S1B; Rougée et al. (2016).

The Simcyp midazolam compound file provides recombinant $\mathrm{V}_{\max }$ and $\mathrm{K}_{\mathrm{m}}$ parameters for CYP3A4 and CYP3A5 conversion of midazolam to the 1'-hydroxymidazolam and 4'-hydroxymidazolam metabolites. These recombinant kinetic parameters were converted to a $\mathrm{HLM} \mathrm{CL}_{\text {int }}$ and only the CYP3A4 1'hydroxymidazolam pathway was further adjusted for the $\mathrm{pH} 7.0$ simulations as described above for (S)-warfarin (Supplemental Material, Table S2, Fig. S1C).

For all inhibitor files, the inhibition parameters $\left(\mathrm{K}_{\mathrm{i}}, \mathrm{K}_{\mathrm{I}}, \mathrm{k}_{\text {inact }}, \mathrm{fu}_{\mathrm{mic}}\right)$ determined in vitro at the different $\mathrm{pH}$ values were used for the separate simulations (Tables 3 and 4). To account for potential differences in the clearance of the inhibitors, the following describes additional changes made to the compound files. The amiodarone and desethylamiodarone compound files previously described in Rougée et al. (2016) were used with the following changes. The amiodarone recombinant $\mathrm{CL}_{\text {int,u }}$ were converted to $\mathrm{HLM} \mathrm{CL}_{\mathrm{int}, \mathrm{u}}$ using the relative abundance of the enzyme in the healthy volunteers population. The HLM $\mathrm{CL}_{\text {int,u }}$ values of all the recombinant pathways were summed to provide a total $\mathrm{HLM} \mathrm{CL}_{\text {int,u }}$, which was further adjusted for the $\mathrm{pH} 7.0$ simulations using our in vitro data. The desethylamiodarone remained unchanged. The baseline Simcyp file for clozapine was used and adjusted in the same manner described above for amiodarone.

Compound files for itraconazole and hydroxyitraconazole were built as described by Chen et al. (2016) with the following exceptions: the clearance of itraconazole to the hydroxyitraconazole metabolite through recombinant CYP3A4 was converted into a HLM $\mathrm{CL}_{\text {int,u }}$ and further adjusted for the $\mathrm{pH}$ 7.0 as previously described above. The hydroxyitraconazole file was unaltered. The baseline Simcyp files for fluconazole and fluvoxamine were used without further changes to the elimination parameters as the clearance for these compounds is provided as an intravenous and oral clearance.

To correct for the differential ionization of the drug between the plasma and the intracellular environments, the $F_{I}$ of each drug was calculated and incorporated into the elimination section of all the compound files, with the exception of fluconazole, fluvoxamine, and desethylamiodarone, as an active uptake into hepatocyte (Table 1; Supplemental Material, Table S2). Fluconazole, fluvoxamine and desethylamiodarone clearance is provided as intravenous or total oral clearance from in vivo data, and therefore would already account for the ionization of the drug and changes in metabolism inside the cell. The inclusion of this correction alters the intracellular concentration of the compound by changing the $\mathrm{Kp}_{\mathrm{uu}}$ to compensate for the difference in $\mathrm{pH}$ between the extracellular and intracellular compartments. The compound files for fluconazole, fluvoxamine and desethylamiodarone implement an in vivo clearance; it was assumed that this clearance already reflects the differential partitioning of the compound into the intracellular compartment compared with the plasma. Therefore, no additional correction for ionization was made.

Simulation dosing schedules were chosen to mimic clinical dosage and clinical DDI studies, if available (Tables 5 and 6); however, for diclofenac, no clinical DDI studies with the perpetrators investigated in this report could be found and therefore, DDI study designs for (S)-warfarin were used. For clozapine, a single dose (900 mg, maximum dose possible) was administered simultaneously with the victim drug and simulated for 24 and 96 hour for diclofenac and (S)-warfarin respectively (Perry et al., 1991). In the case of fluvoxamine, the study design from the midazolam DDI was followed (Lam et al., 2003). All simulations were performed using the Simcyp Healthy Volunteer Population using a 10 by 10 subject trial set up (total population size 100; equal portion male/female, age range 20-50 year) in the fasted state.

Statistical Analysis. The HLM enzyme kinetic parameters $\left(\mathrm{V}_{\mathrm{max}}, \mathrm{K}_{\mathrm{m}}, \mathrm{CL}_{\mathrm{int}}\right)$ for diclofenac, (S)-warfarin, midazolam, and dextromethorphan, as well as $\mathrm{fu}_{\mathrm{mic}}$ values for all drugs, represent the mean of triplicate runs. Mean values of the replicates for $\mathrm{pH} 7.0$ and 7.4 were analyzed for statistical differences with an unpaired, two-tail $t$ test using GraphPad Prism version 6.05 (GraphPad Software, San Diego, CA) using a $\alpha=0.05$. An $F$-test was performed on the nonlinear substrate depletion kinetic model fits for the parent loss data using the same software and $\alpha=0.05$. The ratio of the values obtained at $\mathrm{pH} 7.0$ to values obtained at $\mathrm{pH} 7.4$ are represented in the text of the results section as Ratio ${ }_{7.0: 7.4}$.

\section{Results}

Enzyme kinetic parameters $\mathrm{K}_{\mathrm{m}}, \mathrm{V}_{\max }$ and $\mathrm{CL}_{\mathrm{int}}$ varied with incubation $\mathrm{pH}$ for all substrates investigated for CYP2C9 and CYP3A4, but no clear trend was observed with increased abundance of ionized or un-ionized form of the drugs (Figs. 1 and 2).

Impact of pH on CYP2C9 Enzyme Kinetics. The greatest affinity (lowest $\mathrm{K}_{\mathrm{m}}$ values) were observed at $\mathrm{pH}$ 6.0, while $\mathrm{V}_{\max }$ values peaked 
TABLE 1

Physicochemical properties of CYP2C9 and CYP3A4 substrates and inhibitors

\begin{tabular}{|c|c|c|c|c|}
\hline Compound & Type & $\mathrm{pK}_{\mathrm{a} 1} / \mathrm{pK}_{\mathrm{a} 2}$ & Ionization Factor & Designation \\
\hline Diclofenac & Acid & $4.01^{a}$ & 0.398 & Substrate $^{d}$ \\
\hline (S)-warfarin & Acid & $5.1^{a}$ & 0.401 & Substrate $^{d}$ \\
\hline Dextromethorphan & Base & $8.3^{a}$ & 2.343 & Substrate $^{e}$ \\
\hline Midazolam & Ampholyte & 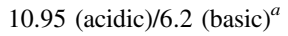 & 1.090 & Substrate ${ }^{e}$ \\
\hline Testosterone & Neutral & - & 1.000 & Substrate $^{e}$ \\
\hline Amiodarone & Base & $8.47^{b}$ & 2.393 & $\begin{array}{l}\text { Reversible inhibitor }{ }^{d, e} ; \\
\quad \text { Time-dependent inhibitor } \\
d, e\end{array}$ \\
\hline Desethylamiodarone & Base & $9.4^{b}$ & 2.497 & Reversible inhibitor $^{d, e}$ \\
\hline Clozapine & Base & $7.75^{a}$ & 2.045 & Reversible inhibitor $^{d}$ \\
\hline Nicardipine & Base & $8.18^{b}$ & 2.297 & Reversible inhibitor $^{d}$ \\
\hline Fluconazole & Base & $1.76^{a}$ & 1.000 & Reversible inhibitor ${ }^{d, e}$ \\
\hline Fluvoxamine & Base & $8.7^{a}$ & 2.440 & Reversible inhibitor ${ }^{d, e}$ \\
\hline Itraconazole & Base & $3.7^{c}$ & 1.000 & Reversible inhibitor $^{e}$ \\
\hline
\end{tabular}

${ }^{a}$ Simcyp.

${ }^{b}$ The Human Metabolome Database (http://www.hmdb.ca)

${ }^{c}$ FDA Label.

${ }^{d} \mathrm{CYP} 2 \mathrm{C}$.

${ }^{e} \mathrm{CYP} 3 \mathrm{~A} 4$.

at $\mathrm{pH} 7.0$ for both the CYP2C9 substrates diclofenac and (S)-warfarin (Fig. 1, B, C, F, G). The $\mathrm{CL}_{\text {int }}$, calculated as $\mathrm{V}_{\max } / \mathrm{K}_{\mathrm{m}}$, was highest at $\mathrm{pH}$ 7.0 for diclofenac and $\mathrm{pH} 6.5$ for (S)-warfarin (Fig. 1, D and H). When comparing $\mathrm{pH}$ values 7.0 and 7.4, represented as the ratio of the values obtained at pH 7.0 to values obtained at $\mathrm{pH} 7.4$ ( Ratio $\left._{7.07 .4}\right), \mathrm{K}_{\mathrm{m}}$ was decreased (higher affinity) at $\mathrm{pH} 7.0$ compared with $\mathrm{pH} 7.4$ with Ratio $7.0: 7.4$ of $0.9(P=0.022)$ and $0.8(P=0.017)$ for diclofenac and $(\mathrm{S})$-warfarin respectively. Conversely, the $\mathrm{V}_{\max }$ was higher at $\mathrm{pH} 7.0$ compared with $\mathrm{pH} 7.4$ for $(\mathrm{S})$-warfarin $\left(\right.$ Ratio $\left._{7.0: 7.4}=1.5 ; P=0.011\right)$ but showed no statistically significant change for diclofenac $\left(\right.$ Ratio $_{7.0: 7.4}=1.1 ; P=$ 0.18). The calculated $\mathrm{CL}_{\text {int }}$ was higher for both substrates at $\mathrm{pH} 7.0$ compared with pH 7.4, with Ratio ${ }_{7.0: 7.4}$ of $1.5(P=0.09)$ and $1.9(P=$ $0.005)$ for diclofenac and (S)-warfarin respectively.

Impact of pH on CYP3A4 Enzyme Kinetics. Affinity of CYP3A4 toward the compounds was variable with the lowest $\mathrm{K}_{\mathrm{m}}$ observed at $\mathrm{pH}$ 7.2, 9.0, and 6.5 for midazolam, dextromethorphan and testosterone respectively (Fig. 2, B, F, J). Observed $\mathrm{V}_{\max }$ and $\mathrm{CL}_{\text {int }}$ peaks were less variable with midazolam and testosterone peaking at $\mathrm{pH} 7.2$ for both enzyme kinetic parameters and dextromethorphan peaking at $\mathrm{pH} 8.0$ and pH 9.0 respectively (Fig. 2, C, D, G, H, K, L). Comparison of Km values $\mathrm{pH} 7.0$ and 7.4 revealed a higher Ratio $7.0: 7.4$ for midazolam $\left(\right.$ Ratio $_{7.0: 7.4}=$ $1.2 ; P=0.25)$ and dextromethorphan $\left(\right.$ Ratio $\left._{7.0: 7.4}=1.7 ; P=0.0002\right)$, while testosterone had increased affinity at $\mathrm{pH} 7.0\left(\right.$ Ratio $_{7.0: 7.4}=0.8 ; P=$ 0.005 ). While $\mathrm{V}_{\max }$ was unaffected for midazolam (Ratio $7.0: 7.4=1.0 ; P=$ 1.0), dextromethorphan $\left(\right.$ Ratio $_{7.0: 7.4}=0.5 ; P=0.0006$ ) and testosterone (Ratio $\left._{7.0: 7.4}=0.8 ; P=0.001\right)$ had statistically significant lower maximal enzyme activity at $\mathrm{pH} 7.0$ compared with $\mathrm{pH}$ 7.4. This resulted in a statistically significant lower $\mathrm{CL}_{\text {int }}$ for dextromethorphan $\left(\right.$ Ratio $_{7.0: 7.4}=$ $0.3 ; P=0.0006)$, while for midazolam $\left(\right.$ Ratio $\left._{7.0: 7.4}=0.8 ; P=0.098\right)$ and testosterone $\left(\right.$ Ratio $\left._{7.0: 7.4}=0.9 ; P=0.173\right)$, the lower $\mathrm{CL}_{\text {int }}$ did not reach significance.

Fraction Unbound in Microsomes. Despite differences in $\mathrm{fu}_{\mathrm{mic}}$ between $\mathrm{pH} 7.0$ and $\mathrm{pH} 7.4$ ( $^{\text {Ratio }}$ 7.0:7.4 ranging from 1.0 to 1.5), no statistical significance was reached for any of the compounds in this study (diclofenac, (S)-warfarin, midazolam, testosterone, fluconazole, fluvoxamine, itraconazole) with the exception of nicardipine
A
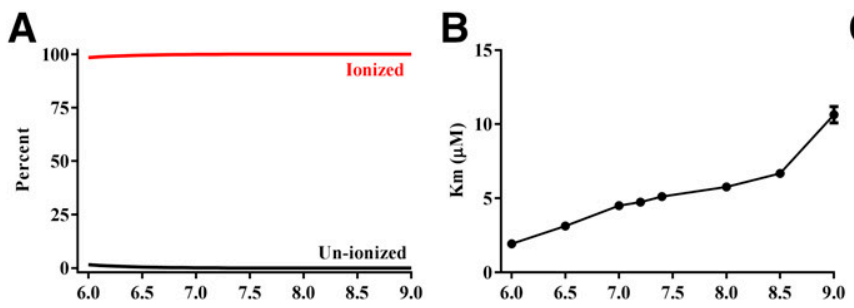

E

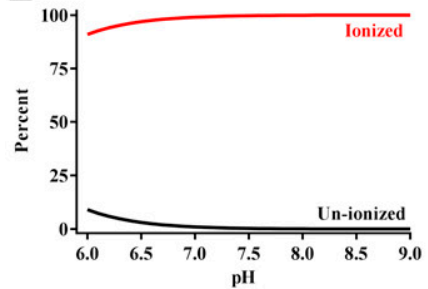

$\mathbf{F}$

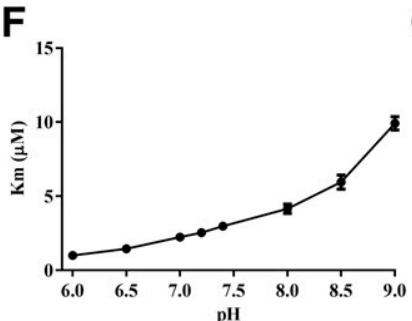

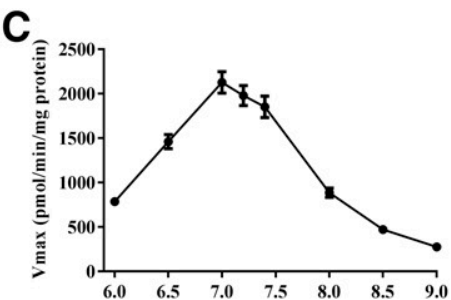

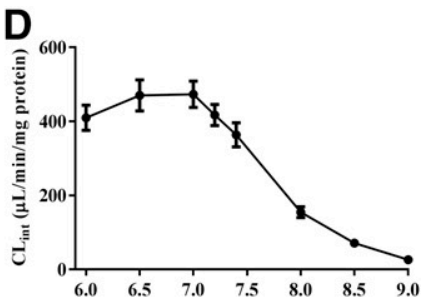

G

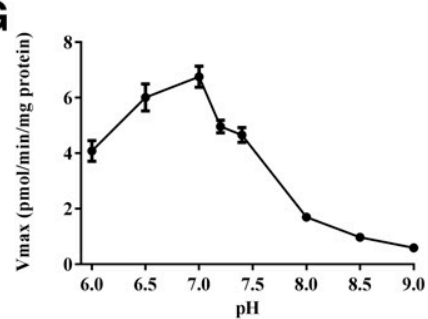

H

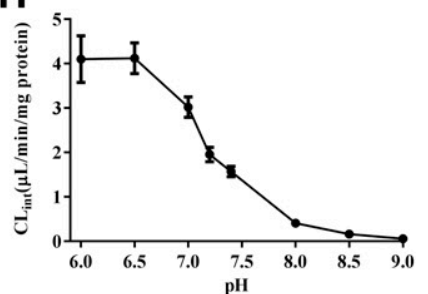

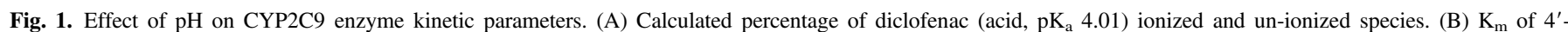

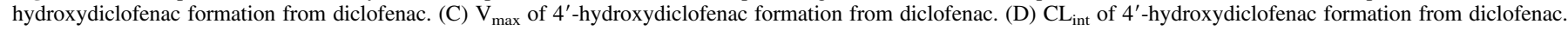

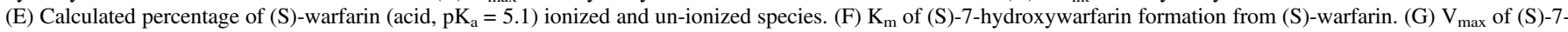

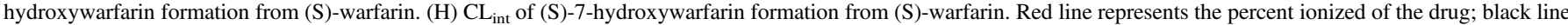
represents the percent un-ionized of the drug. Symbols represent the mean of triplicate determinations, with vertical bars representing SEM. 
A

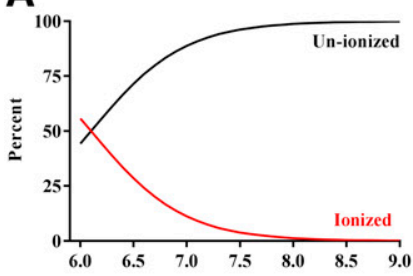

E

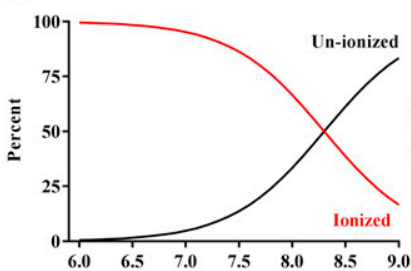

I

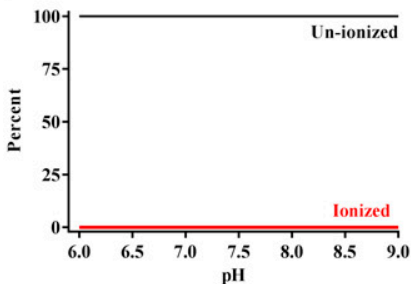

B

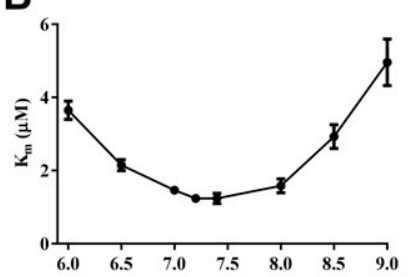

F

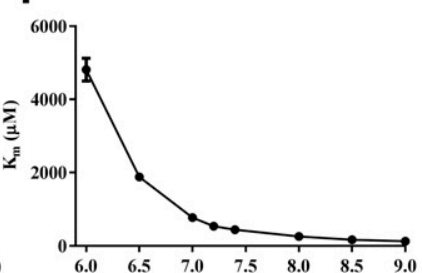

$\mathbf{J}$

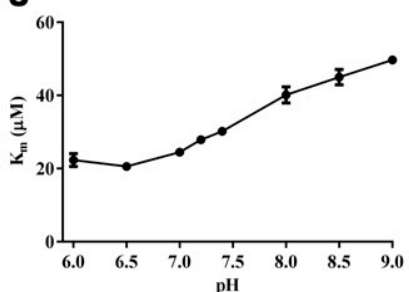

C

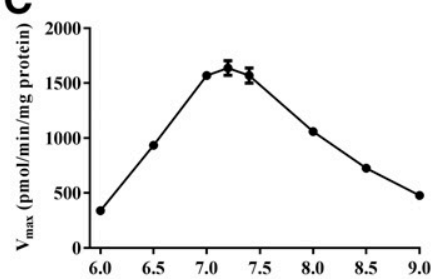

G
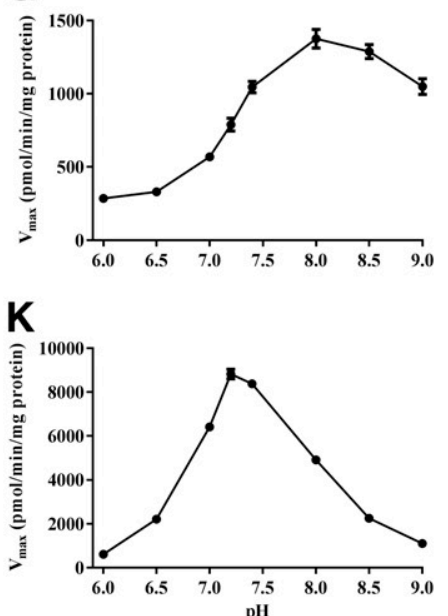

D

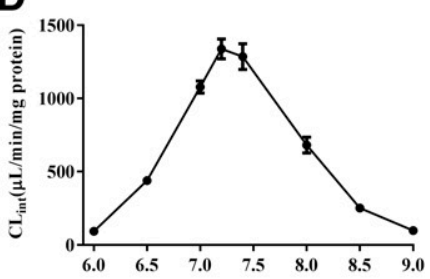

H

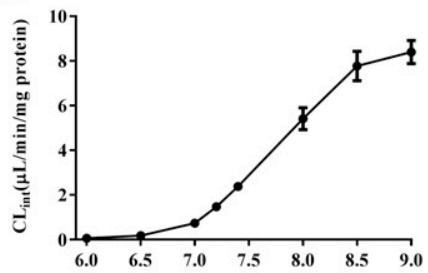

L

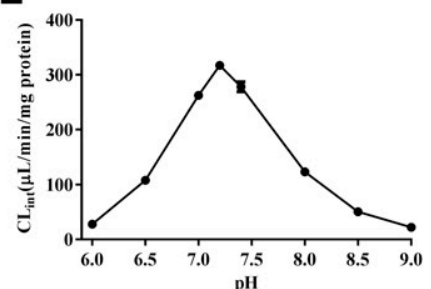

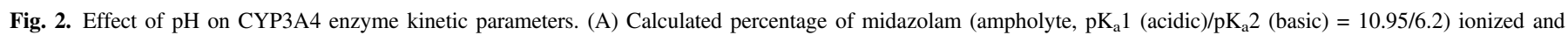

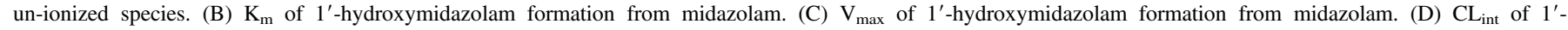

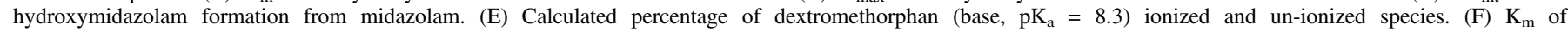

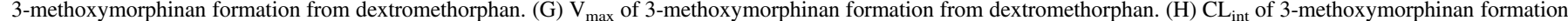

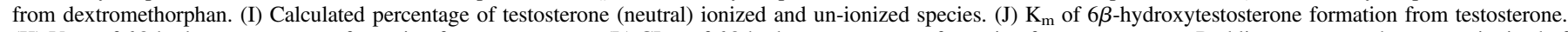

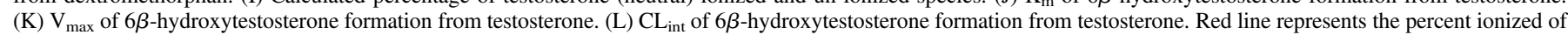
the drug; black line represents the percent un-ionized of the drug. Symbols represent the mean of triplicate determinations, with vertical bars representing SEM.

(Ratio $7.0: 7.4=1.4 ; P=0.023)$. When corrected for $\mathrm{fu}_{\text {mic }}$, the ratios and significances described above for $\mathrm{K}_{\mathrm{m}}$ and $\mathrm{CL}_{\text {int }}$ remained the same except for the Ratio $7.0: 7.4$ for the $\mathrm{K}_{\mathrm{m}}$ for dextromethorphan increased from 1.7 to 1.8 .

Impact of pH on Inhibitor Enzyme Kinetics. The summary of enzyme kinetic parameters determined form the parent loss incubations for the inhibitors studied (amiodarone, clozapine, itraconazole) are summarized in Table 2. Incubation $\mathrm{pH}$ had a significant influence on the total metabolism of amiodarone and clozapine, with $\mathrm{pH} 7.0$ resulting in lower affinity (greater $\mathrm{K}_{\mathrm{m}}$ ) and lower $\mathrm{CL}_{\text {int }}$ compared with $\mathrm{pH} 7.4$ (Fig. 3, A and B; Table 2). The F-test model analysis determined that separate curves were needed to fit the data for each $\mathrm{pH}(P<0.0001$ for both amiodarone and clozapine). Conversely, itraconazole metabolism was not observed to be significantly different $(P=0.218)$, despite a similar trend in the change in enzyme kinetic parameters with $\mathrm{pH}$ (Fig. 3C; Supplemental Material, Table S2).

Impact of pH on Inhibition. Reversible inhibition, described by unbound corrected $\mathrm{K}_{\mathrm{i}}\left(\mathrm{K}_{\mathrm{i}, \mathrm{u}}=\mathrm{K}_{\mathrm{i}} \bullet \mathrm{fu}_{\text {mic }}\right)$ of CYP2C9 by amiodarone, desethylamiodarone, clozapine, nicardipine and fluvoxamine were impacted by $\mathrm{pH}$ (Table 3). Less potent inhibition was observed at $\mathrm{pH}$ 7.0 (larger $\mathrm{K}_{\mathrm{i}, \mathrm{u}}$ ) compared with $\mathrm{pH} 7.4$ (Ratio $_{7.0: 7.4}$ ranging 1.25-2.48). Both victim substrates diclofenac and (S)-warfarin appeared to be

TABLE 2

In vitro metabolism kinetic parameters for inhibitor compounds

Ratio between $\mathrm{pH} 7.0$ and $\mathrm{pH} 7.4$ results are given. The $\mathrm{fu}_{\text {mic }}$ is for inhibitor under in vitro assay condition calculated using equation from Austin et al. (2002).

\begin{tabular}{|c|c|c|c|c|}
\hline Substrate & Parameters & pH 7.0 & pH 7.4 & Ratio $_{7.0: 7.4}$ \\
\hline \multirow{5}{*}{ Amiodarone } & $\mathrm{K}_{\mathrm{m}}(\mu \mathrm{M})$ & $14.97 \pm 3.02$ & $8.66 \pm 1.87$ & 1.7 \\
\hline & $\mathrm{V}_{\max }(\mathrm{nmol} / \mathrm{min}$ per $\mathrm{mg}$ protein $)$ & $1.34 \pm 0.013$ & $1.19 \pm 0.014$ & 1.1 \\
\hline & $\mathrm{CL}_{\text {int }}(\mu \mathrm{l} / \mathrm{min}$ per $\mathrm{mg}$ protein $)$ & $89.20 \pm 4.21$ & $136.92 \pm 7.61$ & 0.7 \\
\hline & $\mathrm{fu}_{\text {mic }}$ & 0.001 & 0.0008 & 1.3 \\
\hline & $\mathrm{K}_{\mathrm{m}}(\mu \mathrm{M})$ & $16.20 \pm 2.56$ & $12.19 \pm 2.66$ & 1.3 \\
\hline \multirow{3}{*}{ Clozapine } & $\mathrm{V}_{\max }(\mathrm{pmol} / \mathrm{min}$ per mg protein) & $257.68 \pm 1.79$ & $322.79 \pm 4.44$ & 0.8 \\
\hline & $\mathrm{CL}_{\text {int }}(\mu \mathrm{l} / \mathrm{min}$ per $\mathrm{mg}$ protein $)$ & $15.91 \pm 0.69$ & $26.48 \pm 1.67$ & 0.6 \\
\hline & $\mathrm{fu}_{\text {mic }}$ & 0.583 & 0.556 & 1.0 \\
\hline \multirow{4}{*}{ Itraconazole } & $\mathrm{K}_{\mathrm{m}}(\mathrm{nM})$ & $27.93 \pm 2.77$ & $20.40 \pm 3.23$ & 1.4 \\
\hline & $\mathrm{V}_{\max }(\mathrm{pmol} / \mathrm{min}$ per mg protein $)$ & $17.14 \pm 0.04$ & $12.75 \pm 0.07$ & 1.3 \\
\hline & $\mathrm{CL}_{\text {int }}(\mu \mathrm{l} / \mathrm{min}$ per $\mathrm{mg}$ protein $)$ & $613.60 \pm 15.00$ & $624.80 \pm 22.90$ & 1.0 \\
\hline & $\mathrm{fu}_{\mathrm{mic}}$ & 0.075 & 0.061 & 1.2 \\
\hline
\end{tabular}


A

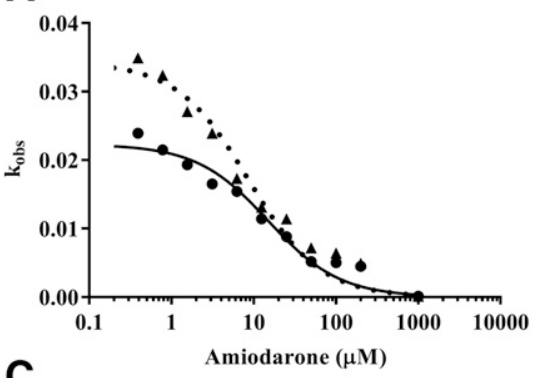

C

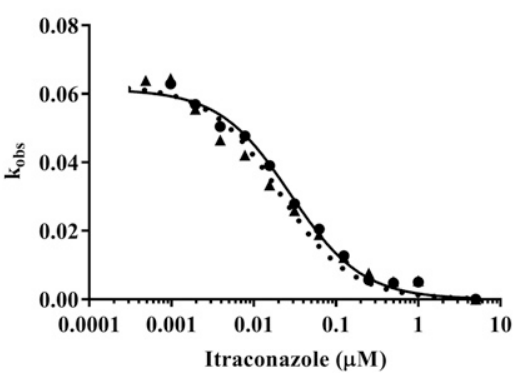

B

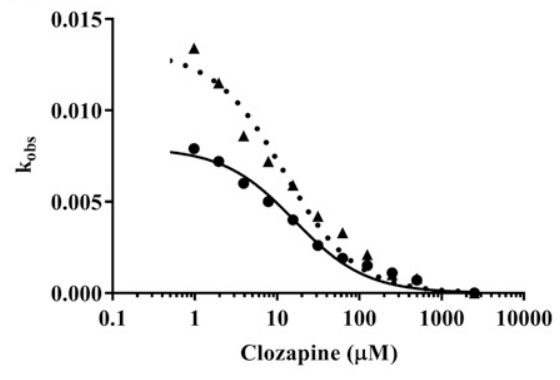

Fig. 3. Substrate depletion curves for the determination of enzyme kinetic parameters performed at $\mathrm{pH} 7.0$ (solid line with circle symbols) and $\mathrm{pH} 7.4$ (dotted line with triangle symbols). (A) Amiodarone depletion. (B) Clozapine depletion. (C) Itraconazole depletion. Symbols represent mean of duplicates. impacted to the same degree (Table 3). However, the impact of $\mathrm{pH}$ on reversible inhibition of CYP3A4, using midazolam as the victim substrate, varied with inhibitor. Amiodarone and itraconazole inhibition was more potent (lower $\mathrm{K}_{\mathrm{i}, \mathrm{u}}$ ) at $\mathrm{pH} 7.0$ compared with $\mathrm{pH} 7.4$ (Ratio $_{7.0: 7.4}=0.7$ for both), while the opposite was observed for desethylamiodarone and fluvoxamine (Ratio $7.0: 7.4$ of 1.2 and 2.1 respectively). Fluconazole inhibition was relatively unchanged between the two $\mathrm{pH}$ values (Ratio $7.0: 7.4=$ 0.9). Time-dependent inhibition of CYP2C 9 and CYP3A4 by amiodarone resulted in similar changes in unbound $\mathrm{K}_{\mathrm{I}}\left(\mathrm{K}_{\mathrm{I}, \mathrm{u}}=\mathrm{K}_{\mathrm{I}} \bullet \mathrm{fu}_{\mathrm{mic}}\right)$ and $\mathrm{k}_{\text {inact }}$ for both enzymes (Fig. 4; Table 4). $\mathrm{K}_{\mathrm{I}, \mathrm{u}}$ was larger (less potent) at pH 7.0 compared with pH 7.4 (Ratio $_{7.0: 7.4}=1.2$ and 1.6 for diclofenac and midazolam respectively). However, the inverse was observed for the enzyme inactivation rate, $\mathrm{k}_{\text {inact }}$, being much lower at $\mathrm{pH} 7.0$ than $\mathrm{pH}$ 7.4 Ratio $_{7.0: 7.4}=0.7$ and 0.8 for diclofenac and midazolam respectively). The only significant reversible inhibition that was observed for the two highest concentrations of amiodarone (26\% and $44 \%$ for 50 and $100 \mu \mathrm{M}$ respectively, compared with solvent control) in the diclofenac secondary incubation.

PBPK Simulations Using In Vitro Parameters. Application of the $F_{I}$ correction alone in simulations for diclofenac and (S)-warfarin, predicted a much greater exposure, 3.0- and 2.1-fold increase respectively, as determined by the area under the concentration-time profile curve (AUC) (Table 5). The $\mathrm{F}_{\mathrm{I}}$ correction resulted in a decrease in intracellular unbound concentration available in the hepatocyte, which translated to a slower rate of elimination, by $60 \%$ and $50 \%$ for diclofenac and (S)-warfarin respectively, compared with the baseline $\mathrm{Sim}_{\mathrm{pH}} 7.4$ simulation. Similar changes remained for diclofenac predictions of clearance and AUC when the $\mathrm{F}_{\mathrm{I}}$ correction was combined with inputs adjusted for changes observed in vitro at $\mathrm{pH} 7.0$ within this study (Table 5). However, the combination of $\mathrm{pH} 7.0$ adjustments and the $\mathrm{F}_{\mathrm{I}}$ correction for $(\mathrm{S})$ warfarin predicted an exposure and clearance within $20 \%$ of the baseline $\operatorname{Sim}_{\mathrm{pH}}$ 7.4. In the case of (S)-warfarin, but not diclofenac, the increase in $\mathrm{CL}_{\text {int }}$ at $\mathrm{pH} 7.0$ compared with $\mathrm{pH} 7.4$ was enough to offset for the decreased intracellular unbound concentration due to the ionization correction (Fig. 1D). The $95 \%$ confidence interval (CI) for clearance and AUC predictions of $\mathrm{Sim}_{\mathrm{pH}} 7.4$ did not overlap with those for $\operatorname{Sim}_{\mathrm{pH}}$ 7.4, FI and $\mathrm{Sim}_{\mathrm{pH}}$ 7.0, FI predictions for both diclofenac and (S)-warfarin. However, the 95\% CI of $\operatorname{Sim}_{\mathrm{pH}}$ 7.4, FI and $\operatorname{Sim}_{\mathrm{pH}}$ 7.0, FI predictions for the clearance of diclofenac and (S)-warfarin, as well as AUC of diclofenac did overlap, while for (S)-warfarin AUC predictions they did not (Table 5).

For dextromethorphan, the ionization correction alone resulted in an increase in intracellular unbound concentration within the hepatocyte, which translated to a 2.2-fold higher rate of elimination and decrease in exposure compared with the baseline simulation without correction. However, adjustment for $\mathrm{pH} 7.0$ in vitro observations in combination with the ionization correction returned exposure and elimination within $20 \%$ of the baseline simulation. Prediction CI for clearance and AUC between $\operatorname{Sim}_{\mathrm{pH}} 7.4$ and $\operatorname{Sim}_{\mathrm{pH}}$ 7.0, FI overlapped, whereas predictions between $\operatorname{Sim}_{\mathrm{pH}}$ 7.4 and $\operatorname{Sim}_{\mathrm{pH}}$ 7.4, FI or $\operatorname{Sim}_{\mathrm{pH}}$ 7.4, FI and $\operatorname{Sim}_{\mathrm{pH}}$ 7.0, FI $\operatorname{did}$ not overlap.

For midazolam, all three simulation scenarios $\left(\operatorname{Sim}_{\mathrm{pH}} 7.4, \mathrm{Sim}_{\mathrm{pH}} 7.4, \mathrm{FI}\right.$, $\operatorname{Sim}_{\mathrm{pH}}$ 7.0, FI) predicted an AUC, clearance and maximum observed concentration within $10 \%$ of each other with overlap of the CIs between all prediction scenarios.

The prediction of DDI, given as the ratio of AUC in the presence of inhibitor to the absence of inhibitor (AUC ratio) for the victimperpetrator combinations are listed in Table 6. Comparison of the simulation scenarios with correction $\left(\operatorname{Sim}_{\mathrm{pH}}\right.$ 7.4, FI or $\operatorname{Sim}_{\mathrm{pH}}$ 7.0, FI $)$ to the baseline $\mathrm{Sim}_{\mathrm{pH}} 7.4$ simulation are reported as a ratio to the baseline $\operatorname{Sim}_{\mathrm{pH}} 7.4$

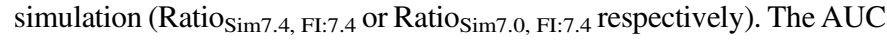
ratio between the simulation scenarios for all diclofenac/inhibitors combinations as well as the (S)-warfarin/clozapine, midazolam/ fluconazole and midazolam/fluvoxamine combinations ranged from 0.95 to 1.02 with $95 \%$ CI overlapping between all three simulation scenarios for (S)-warfarin and midazolam as victim. Prediction $95 \% \mathrm{CI}$ for AUC ratios between $\operatorname{Sim}_{\mathrm{pH}}$ 7.4, FI and $\mathrm{Sim}_{\mathrm{pH}}$ 7.0, FI did not overlap for any of the diclofenac/inhibitor combinations, while the $95 \%$ CI between $\mathrm{Sim}_{\mathrm{pH}} 7.4$ and $\mathrm{Sim}_{\mathrm{pH}}$ 7.4, FI and $\mathrm{Sim}_{\mathrm{pH}} 7.4$ and $\mathrm{Sim}_{\mathrm{pH} \text { 7.0, FI }}$ overlapped in all combinations except for the diclofenac/fluconazole and diclofenac/ clozapine respectively (Table 6).

Simulation scenario $\mathrm{Sim}_{\mathrm{pH}}$ 7.4, FI for (S)-warfarin, in combination with amiodarone or fluconazole, predicted a decrease in AUC ratio

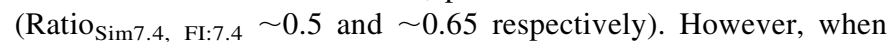
$\mathrm{Sim}_{\mathrm{pH}}$ 7.0, FI conditions were used, the AUC ratio returned to within $20 \%$ or less of the $\operatorname{Sim}_{\mathrm{pH}} 7.4$ baseline predictions (Ratio ${ }_{\text {Sim7.0, FI:7.4 }} 0.8$ and 
TABLE 3

Reversible CYP2C9 and CYP3A4 inhibition kinetic parameters at $\mathrm{pH} 7.0$ and $\mathrm{pH} 7.4$

Ratio between $\mathrm{K}_{\mathrm{i}, \mathrm{u}}$ at $\mathrm{pH} 7.0$ to $\mathrm{K}_{\mathrm{i}, \mathrm{u}}$ at $\mathrm{pH} 7.4$ is given.

\begin{tabular}{|c|c|c|c|c|c|c|}
\hline Substrate & Inhibitor & $\mathrm{fu}_{\text {mic, }} \mathrm{pH} 7.0$ & $\mathrm{~K}_{\mathrm{i}, \mathrm{u} \text { pH } 7.0}$ & $\mathrm{fu}_{\text {mic, }} \mathrm{pH} 7.4$ & $\mathrm{~K}_{\mathrm{i}, \mathrm{u} \mathrm{pH}} 7.4$ & $\mathrm{~K}_{\mathrm{i}, \mathrm{u}}$ \\
\hline & & & $\mu \mathrm{M}$ & & $\mu \mathrm{M}$ & Ratio $_{7.0: 7.4}$ \\
\hline \multirow[t]{6}{*}{ Diclofenac } & Amiodarone $^{a}$ & $0.0026^{b}$ & $0.163 \pm 0.01$ & $0.0020^{b}$ & $0.130 \pm 0.01$ & 1.25 \\
\hline & Desethylamiodarone $^{c}$ & $0.0057^{b}$ & $0.128 \pm 0.023$ & $0.0054^{b}$ & $0.081 \pm 0.01$ & 1.58 \\
\hline & Clozapine $^{d}$ & $0.870^{b}$ & $27.31 \pm 1.72$ & $0.859^{b}$ & 11.120 .464 & 2.46 \\
\hline & Nicardipine $^{d}$ & $0.440^{e}$ & $0.088 \pm 0.006$ & $0.334^{e}$ & 0.0550 .004 & 1.61 \\
\hline & Fluconazole $^{d}$ & $0.996^{e}$ & $39.86 \pm 1.39$ & $0.995^{e}$ & $35.82 \pm 0.87$ & 1.11 \\
\hline & Fluvoxamine $^{d}$ & $0.855^{e}$ & $21.98 \pm 1.08$ & $0.822^{e}$ & $8.87 \pm 0.23$ & 2.48 \\
\hline \multirow[t]{6}{*}{ (S)-warfarin } & Amiodarone $^{d}$ & $0.0010^{b}$ & $0.040 \pm 0.005$ & $0.0008^{b}$ & $0.024 \pm 0.002$ & 1.65 \\
\hline & Desethylamiodarone $^{c}$ & $0.0023^{b}$ & 0.0520 .007 & $0.0022^{b}$ & $0.037 \pm 0.004$ & 1.40 \\
\hline & Clozapine $^{d}$ & $0.732^{b}$ & $16.67 \pm 1.18$ & $0.712^{b}$ & $11.92 \pm 0.668$ & 1.40 \\
\hline & Nicardipine $^{d}$ & 0.239 & $0.428 \pm 0.038$ & 0.167 & $0.244 \pm 0.02$ & 1.76 \\
\hline & Fluconazole $^{d}$ & 0.991 & $11.56 \pm 1.18$ & 0.987 & $11.28 \pm 1.0$ & 1.02 \\
\hline & Fluvoxamine $^{d}$ & 0.702 & $7.93 \pm 0.78$ & 0.649 & $3.19 \pm 0.3$ & 2.48 \\
\hline \multirow[t]{5}{*}{ Midazolam } & Amiodarone $^{c}$ & $0.0051^{b}$ & $0.258 \pm 0.063$ & $0.0040^{b}$ & $0.377 \pm 0.105$ & 0.69 \\
\hline & Desethylamiodarone $^{a}$ & $0.0113^{b}$ & $0.132 \pm 0.012$ & $0.0107^{b}$ & $0.109 \pm 0.008$ & 1.21 \\
\hline & Fluconazole $^{c}$ & $0.998^{e}$ & $5.09 \pm 0.60$ & $0.997^{e}$ & $5.43 \pm 0.670$ & 0.94 \\
\hline & Fluvoxamine ${ }^{c}$ & $0.922^{e}$ & $65.2 \pm 6.8$ & $0.902^{e}$ & $31.2 \pm 3.6$ & 2.09 \\
\hline & Itraconazole $^{d}$ & $0.139^{e}$ & $1.54 \pm 0.14^{f}$ & $0.114^{e}$ & $2.34 \pm 0.19^{f}$ & 0.66 \\
\hline
\end{tabular}

${ }^{a}$ Noncompetitive inhibition model.

${ }^{b} \mathrm{fu}_{\text {mic }}$ values from Rougée et al. (2016).

${ }^{c}$ Mixed inhibition model.

${ }^{d}$ Competitive inhibition model.

${ }^{e} \mathrm{fu}_{\text {mic }}$ for inhibitor under in vitro assay conditions calculated using equation from Austin et al. (2002) and in vitro determinations.

${ }^{f}$ Results for itraconazole given in nanomolar units.

0.9 for amiodarone and fluconazole respectively). Despite this, the $95 \% \mathrm{CI}$ for all scenario predictions did not overlap. Comparing the (S)-warfarin interaction studies to clinically observed DDI, the findings are mixed. In the case of amiodarone, while all scenarios over predicted the interaction, the inclusion of only the ionization correction provided a prediction closer to the clinical observations, within 2.5-fold. For fluconazole, predictions using the dosing schedule from Neal et al. (2003) resulted in the same observations as described above for amiodarone; however, for the study by Black et al. (1996), the $\mathrm{Sim}_{\mathrm{pH}}$ 7.0, FI Scenario prediction was more reflective of the clinical study findings.

No substantial difference was observed between the baseline $\operatorname{Sim}_{\mathrm{pH}} 7.4$ and $\operatorname{Sim}_{\mathrm{pH}}$ 7.4, FI simulations for the midazolam/itraconazole combination as the $95 \%$ CI overlapped. However, $\mathrm{Sim}_{\mathrm{pH}}$ 7.0, FI resulted in predicted AUC ratios on average $25 \%$ higher than the baseline simulation with no overlap in the $95 \%$ CI predictions. While the majority of scenario predictions were substantially lower than clinical reported DDI results, the $\operatorname{Sim}_{\mathrm{pH}}$ 7.0, FI AUC ratios were in all cases an improvement on the interaction prediction of midazolam/itraconazole compared with the clinical reports.

\section{Discussion}

To account for the effect of the plasma to cell concentration gradient on drug distribution, the $\mathrm{F}_{\mathrm{I}}$ correction has been applied. The application of the $F_{I}$ correction rests on three assumptions: 1) the drug is not subject to active transport, 2) the total unbound concentration and not a particular species (ionized or un-ionized) determines the rate of association between drug and enzyme, and 3 ) in vitro determinations of the $\mathrm{K}_{\mathrm{m}}, \mathrm{V}_{\max }, \mathrm{CL}_{\mathrm{int}}$ and $\mathrm{fu}_{\text {mic }}$ generated at $\mathrm{pH} 7.4$ can be used as there is no significant difference with data generated at $\mathrm{pH}$ 7.0 (Berezhkovskiy et al., 2012). These assumptions have been addressed previously (Rougée et al., 2016) for CYP2D6 substrates and inhibitors, and with this current study for CYP2C9 and CYP3A4 substrates to cover a broad range of compounds (acid, base, neutral) in an attempt to uncover general relationships.

Over the wide range of compounds studied to date there is no clear evidence that a particular species of a substrate drives the reaction. Testosterone is a neutral compound that provides direct evidence that the un-ionized form can drive P450 turnover. In the case of diclofenac and (S)-warfarin, acids will exist predominantly ( $>98 \%$ and $90 \%$ respectively) in the ionized form over the $\mathrm{pH}$ range investigated, it could be speculated that the ionized form of the substrate drives the catalytic rate. However, observations of the affinity $\left(\mathrm{K}_{\mathrm{m}}\right)$ of CYP2C9 toward diclofenac and (S)-warfarin appeared to trend with the un-ionized species of either substrate. While there is only a small change in species abundance, less than $2 \%$ and $10 \%$ change over the $\mathrm{pH}$ range for diclofenac and (S)-warfarin respectively, the $\mathrm{K}_{\mathrm{m}}$ of CYP2C9 appears to increase with increasing $\mathrm{pH}$, corresponding to the disappearance of the un-ionized species. This same trend was observed for CYP2D6 and CYP3A4 toward the un-ionized species of dextromethorphan (current study, Rougée et al., 2016). However, the magnitude of change observed in the substrate ionization and $\mathrm{K}_{\mathrm{m}}$ between the different $\mathrm{pH}$ values, did
A

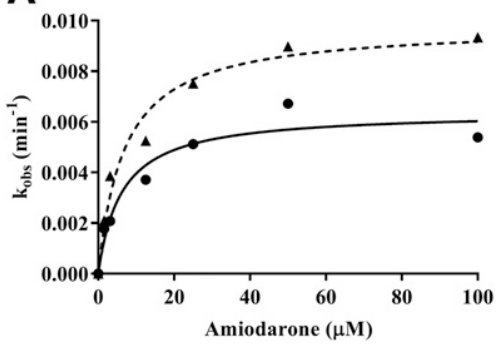

B

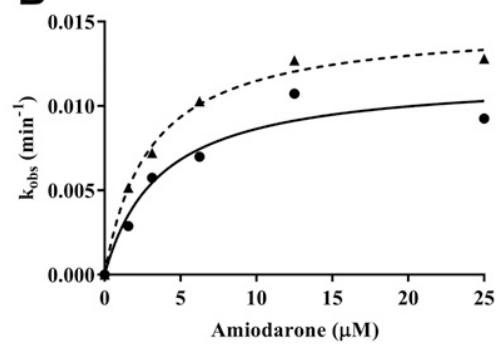

Fig. 4. Pseudo first-order inhibition rate constants for loss of CYP2C9 and CYP3A4 activity verses inhibitor concentration performed at $\mathrm{pH} 7.0$ (solid line with circle symbols) and $\mathrm{pH} 7.4$ (dashed line with triangle symbols). (A) Amiodarone inhibition of 4 'hydroxydiclofenac formation from diclofenac. (B) Amiodarone inhibition of 1 'hydroxymidazolam formation from midazolam. Symbols represent mean of duplicates. 
TABLE 4

Time-dependent inhibition parameters of amiodarone toward CYP2C9 and CYP3A4 at $\mathrm{pH} 7.0$ and $\mathrm{pH} 7.4$

Results for the ratio between $\mathrm{pH} 7.0$ and $\mathrm{pH} 7.4$ are given. The $\mathrm{fu}_{\text {mic }}$ is for inhibitor under in vitro assay condition prior to dilution (0.5 mg/ml) calculated using equation from Austin et al. (2002) and values previously reported by Rougée et al. (2016).

\begin{tabular}{|c|c|c|c|c|c|c|c|c|c|c|}
\hline Enzyme & Substrate & Inhibitor & $\mathrm{fu}_{\text {mic,pH }} 7.0$ & $\mathrm{~K}_{\mathrm{I}, \mathrm{u} \mathrm{pH} 7.0}$ & $\mathrm{k}_{\text {inact }, \mathrm{pH}} 7.0$ & $\mathrm{fu}_{\text {mic,pH }} 7.4$ & $\mathrm{~K}_{\mathrm{I}, \mathrm{u} \mathrm{pH} 7.4}$ & $\mathrm{k}_{\text {inact }, \mathrm{pH}} 7.4$ & $\mathrm{~K}_{\mathrm{I}, \mathrm{u}}$ & $\mathrm{K}_{\text {inact }}$ \\
\hline & & & & $\mathrm{nM}$ & $\min ^{-1}$ & & $\mathrm{nM}$ & $\min ^{-1}$ & Ratio $_{7.0: 7.4}$ & Ratio $_{7.0: 7.4}$ \\
\hline CYP2C9 & Diclofenac & Amiodarone & 0.0004 & $3.16 \pm 1.19$ & $0.006 \pm 0.0006$ & 0.0005 & $2.75 \pm 0.70$ & $0.010 \pm 0.0006$ & 1.15 & 0.65 \\
\hline CYP3A4 & Midazolam & Amiodarone & 0.0004 & $1.87 \pm 0.72$ & $0.012 \pm 0.001$ & 0.0005 & $1.19 \pm 0.16$ & $0.015 \pm 0.0006$ & 1.57 & 0.79 \\
\hline
\end{tabular}

not correlate nor follow the same pattern. Measurement of $\mathrm{V}_{\max }$ for these enzyme/substrate combinations lacked concordance with the $\mathrm{K}_{\mathrm{m}}$ findings, with $\mathrm{V}_{\max }$ changes not correlating to either species of the substrates. Although the ionized and un-ionized forms of bufuralol and midazolam changed drastically over the $\mathrm{pH}$ 6.0-9.0 range, no direct correlation between a single form of the substrate and the enzyme kinetic parameters $\left(\mathrm{K}_{\mathrm{m}}, \mathrm{V}_{\max }\right)$ was observed, thus suggesting that the total concentration of substrate is responsible.

One limitation when interpreting these experimental findings is that the change in $\mathrm{pH}$ results in altered charged states of both drug and enzyme. While there is structural conservation at the core of the P450 enzymes, the regions that form the outer surface of the enzyme can vary significantly (Johnson and Stout, 2005). These differences lead to changes in size, shape and substrate discrimination. CYP2C9 predominantly metabolizes acidic compounds that have a negative charge present at physiologic pH (Zhou et al., 2009). While the basic amino acid residue, Arg108, plays an important role in stabilizing the binding of anionic substrates in the catalytic active site (de Groot et al., 2002; Wester et al., 2004), hydrogen bonding with charged residues at the entrance/access tunnel of the active site have also been shown to be responsible for the binding and positioning of anionic substrates toward the heme (de Groot et al., 2002; Williams et al., 2003; Cojocaru et al., 2012). Therefore, due to the external facing position of the residues responsible, $\mathrm{pH}$ of the external environment could critically alter the ion-pair interactions. A caveat to results of crystallography studies is that the enzymes are typically prepared in solutions at $\mathrm{pH} 7.4$ and therefore structural determinations and changes from binding with compounds may not be reflective of in vivo. Regardless of these stipulations, when conducting enzyme reactions under $\mathrm{pH}$ 7.0, the interaction between enzyme and compound form should exist as they would in vivo, in the intracellular environment.

This concept is strengthened by our findings that in vitro measurements performed at $\mathrm{pH} 7.0$ can be significantly different than those at $\mathrm{pH}$ 7.4 , which is inconsistent with the final assumption of the ionization correction (Berezhkovskiy, 2011; Berezhkovskiy et al., 2012). Metabolism, $\mathrm{fu}_{\mathrm{mic}}$, and inhibition appear to be affected by $\mathrm{pH}$ on an enzyme/ substrate/inhibitor basis. Although some generalizations can be made including decreased $\mathrm{CL}_{\text {int }}$ for basic compounds and increased $\mathrm{CL}_{\text {int }}$ for acidic compounds at $\mathrm{pH} 7.0$ compared with $\mathrm{pH} 7.4$, presumably offsetting the increase and decrease of the intracellular drug concentration respectively, this is not always the situation. Furthermore, inhibition potency was observed to decrease at $\mathrm{pH} 7.0$ compared with $\mathrm{pH} 7.4$ for all CYP2C9 inhibitors except fluconazole. However, the potency of some of the same inhibitors for CYP2C9 responded differently at certain $\mathrm{pH}$ values for CYP2D6 and CYP3A4. Combining this with a variation in response for enzyme/substrate/inhibitor combinations investigated, precludes making generalization to other substrates, inhibitors and enzymes.

Importance of the ionization correction in the absence or presence of in vitro parameters obtained at the different $\mathrm{pH}$ values can be assessed using PBPK models that rely on intracellular concentration and in vitro inputs when using a "bottom-up" approach. Inclusion of the $\mathrm{F}_{\mathrm{I}}$ correction alone can change exposure predictions through alterations in the sequestration of drug in either plasma or the hepatocyte intracellular space. These changes in intracellular concentration brought forth by the ionization correction appear to be, for the most part, offset by changes in the enzyme kinetic parameters determined at $\mathrm{pH} 7.0$ for the $\mathrm{P} 450$ enzymes investigated. Although inclusion of changes in CYP2C9 kinetic parameters

TABLE 5

Simulated pharmacokinetic parameters for CYP2C9 and CYP3A4 substrates

Dose of diclofenac $(50 \mathrm{mg})$, midazolam $(7.5 \mathrm{mg})$, and dextromethorphan $(30 \mathrm{mg})$ simulated for $24 \mathrm{~h}$ and (S)-warfarin $(12.5 \mathrm{mg})$ simulated for $168 \mathrm{~h}$. Geometric means reported with fold difference between simulation and baseline $\mathrm{Sim}_{\mathrm{pH}} 7.4$ given in parentheses. AUC, area under the concentration-time profile curve CI, confidence interval; CL, clearance calculated as Dose/AUC; Cmax, maximum observed concentration. The 95\% confidence interval of the model predictions is listed in brackets.

\begin{tabular}{|c|c|c|c|c|c|}
\hline & & \multicolumn{3}{|c|}{ Simulation } & \multirow[b]{2}{*}{ Observed } \\
\hline & & $\operatorname{Sim}_{\mathrm{pH} 7.4}[95 \% \mathrm{CI}]$ & $\operatorname{Sim}_{\mathrm{pH}} 7.4, \mathrm{FI}[95 \% \mathrm{CI}]$ & $\operatorname{Sim}_{\mathrm{pH}}$ 7.0, FI $[95 \% \mathrm{CI}]$ & \\
\hline & $\mathrm{CL}(\mathrm{l} / \mathrm{h})$ & 31.53 [28.83-34.49] & $13.83(0.4)[12.72-15.04]$ & $15.24(0.5)$ [13.99-16.61] & 29.9 \\
\hline \multirow[t]{3}{*}{ Diclofenac } & $\mathrm{C}_{\max }(\mathrm{mg} / \mathrm{l})$ & $1.22[1.13-1.32]$ & 1.77 (1.4) [1.64-1.90] & 1.69 (1.4) [1.57-1.82] & $2.0^{a}$ \\
\hline & AUC (mg/l-h) & $1.59[1.45-1.73]$ & $3.62(3.0)[3.33-3.93]$ & $3.28(2.7)[3.01-3.57]$ & $1.67^{a}$ \\
\hline & $\mathrm{CL}(1 / \mathrm{h})$ & $276.40[248.47-307.47]$ & $133.06(0.5)[121.69-145.50]$ & $222.10(0.8)$ [200.49-246.03] & 207.6 \\
\hline \multirow[t]{3}{*}{ (S)-warfarin } & $\mathrm{C}_{\max }(\mathrm{mg} / \mathrm{l})$ & $1.30[1.21-1.40]$ & $1.36(1.0)[1.26-1.46]$ & $1.31(1.0)[1.22-1.42]$ & $1.84^{b}$ \\
\hline & $\operatorname{AUC}(\mathrm{mg} / \mathrm{l} \cdot \mathrm{h})$ & $45.22[40.65-50.31]$ & 93.94 (2.1) [85.91-102.72] & $56.28(1.2)[50.81-62.35]$ & $60.22^{b}$ \\
\hline & $\mathrm{CL}(1 / \mathrm{h})$ & $85.52[74.40-98.30]$ & 93.12 (1.1) [81.00-107.05] & 93.12 (1.1) [81.00-107.05] & 81.52 \\
\hline \multirow[t]{3}{*}{ Midazolam } & $\mathrm{C}_{\max }(\mathrm{mg} / \mathrm{l})$ & 23.15 [20.62-25.99] & $22.08(1.0)[19.64-24.82]$ & $22.08(1.0)[19.64-24.82]$ & $34^{c}$ \\
\hline & AUC $(\mathrm{mg} / \mathrm{l} \cdot \mathrm{h})$ & $87.70[76.29-100.80]$ & $80.54(0.9)[81.00-107.05]$ & $80.54(0.9)[81.00-107.05]$ & $92^{c}$ \\
\hline & CL $(1 / h)$ & $500.48[418.62-598.33]$ & $1084.12(2.2)[888.42-1322.93]$ & 603.19 (1.2) [503.91-722.04] & 845.1 \\
\hline \multirow[t]{2}{*}{ Dextromethorphan } & $\mathrm{C}_{\max }(\mathrm{mg} / \mathrm{l})$ & $5.18[4.41-6.09]$ & $2.63(0.5)[2.18-3.17]$ & $4.45(0.9)[3.77-5.26]$ & $3.49^{d}$ \\
\hline & $\operatorname{AUC}(\mathrm{mg} / \mathrm{l} \cdot \mathrm{h})$ & $59.94[50.14-71.66]$ & $27.67(0.5)$ [22.68-33.77] & $49.74(0.8)[41.55-59.53]$ & $35.5^{d}$ \\
\hline
\end{tabular}

${ }^{a}$ Willis et al. (1979)

${ }^{b}$ Braeckman et al. (2014), assuming $12.5 \mathrm{mg}$ (S)-warfarin from racemic mixture dose of $25 \mathrm{mg}$.

${ }^{c}$ Bornemann et al. (1985).

${ }^{d}$ Chi et al. (2013). 


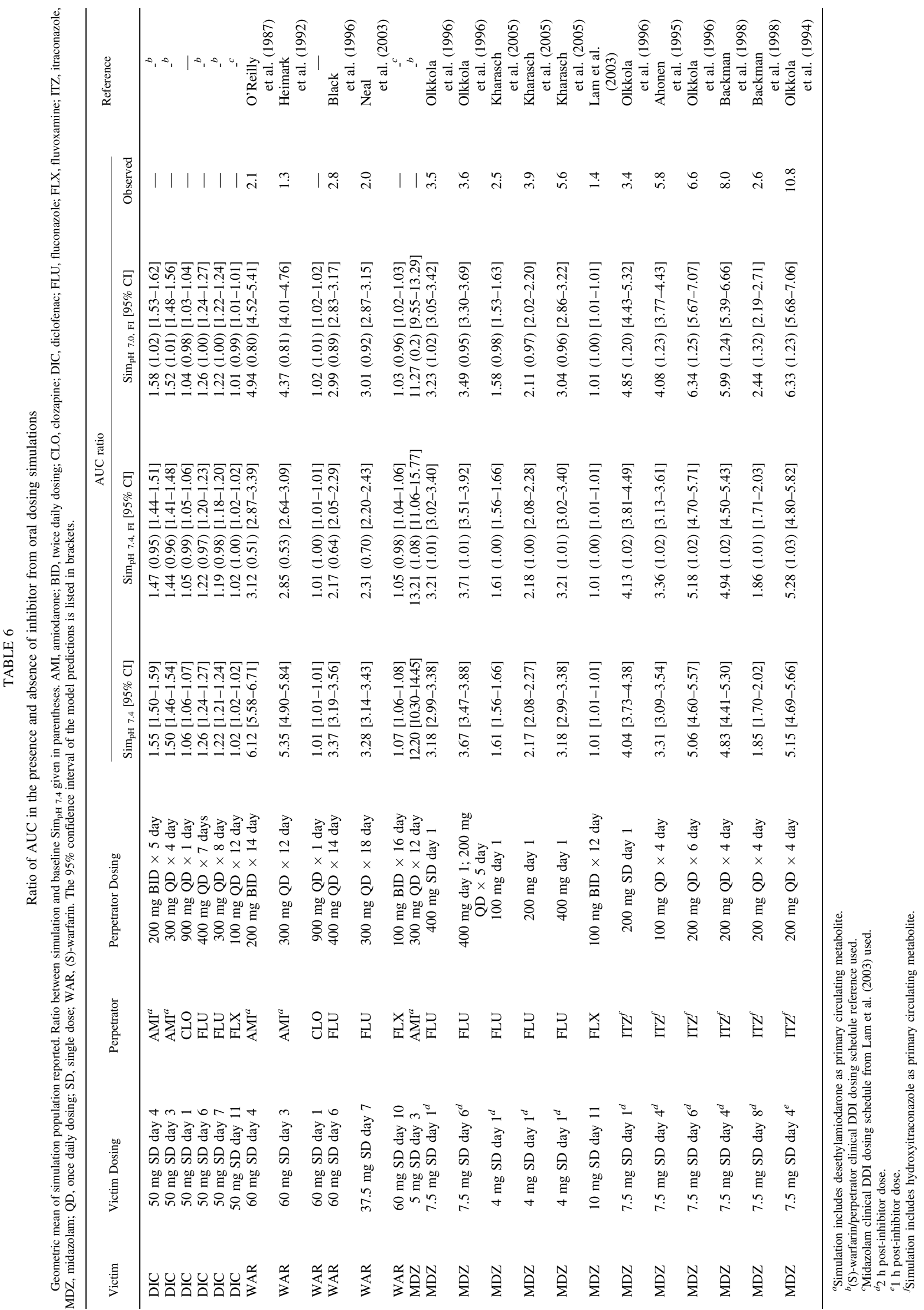


at $\mathrm{pH} 7.0$ did not appear to alter the clearance predictions for diclofenac, it is one of two metabolic pathways. While CYP2C9 is a major metabolizing enzyme for diclofenac, the fraction metabolized by this pathway is approximately $40 \%$ with the remaining fraction performed by the uridine diphosphate-glucuronosyltransferase (UGT) 2B7 enzyme (Kilford et al., 2009). Since $\mathrm{P} 450$ enzymes can be sensitive to $\mathrm{pH}$, it is conceivable that metabolism through UGT enzymes may also be affected and this requires further investigation. Lastly, while several measured parameters did not result in statistically significant different values between $\mathrm{pH} 7.0$ and $\mathrm{pH}$ 7.4 , the differences in each parameter, when combined, can have a collective effect that can influence the prediction outcomes. It is important to recognize that for this study, pre-optimized PBPK models were used as the starting point and only metabolism and intercellular concentration were subsequently altered. These adjustments account for only a fraction of the complete model inputs and illustrate the consequences resulting when not all inputs are incorporated. To effectively make predictions, in vitro parameters using HLM, as well as other intracellular inputs exposed to different conditions compared with the extracellular environment, should be determined under conditions that mimic in vivo physiology when these inputs are combined with the correction of intracellular concentration resulting from drug ionization.

The discordance between in vitro and in vivo findings remains a subject of intense investigation. Implementation of the $\mathrm{F}_{\mathrm{I}}$ correction requires the use of in vitro data generated at the intracellular $\mathrm{pH}$ 7.0. Our findings suggest that the significant changes in vitro measurements at $\mathrm{pH}$ 7.0 offset the intracellular concentration changes from the $F_{I}$ correction. Combined with overlapping confidence intervals of the predictions between the different simulation scenarios suggests that in general there is no statistically significant improvement in predictions. However, other correction factors, such as active transport should also be considered. For example, predictions with quinidine as a perpetrator have under predicted clinical DDIs. Inhibition potency using HLM was shown to be significantly less $(>10$-fold) than inhibition potency determined in hepatocytes, a difference much greater than the $F_{I}$ correction alone. This difference is likely a result of rapid and extensive cellular uptake into the hepatocyte (Englund et al., 2014), combined with slower metabolism of quinidine at the intracellular pH 7.0 (Rougée et al., 2016). While adjustment of the slower metabolism and some intracellular accumulation can be made using HLM, this data must be combined with cellular uptake to effectively predict the true interaction.

Although the current state of knowledge demonstrates the sensitivity of metabolic kinetic parameters to $\mathrm{pH}$, these changes are all within threefold, remain on an enzyme/substrate/inhibitor basis, and are not large enough to influence compound selection in early discovery. As a drug moves into development, where predictability and translational ability of the in vitro data to in vivo becomes of great importance, even subtle changes in in vitro measurements can have a significant impact on predictions, as reported here where some predictions using both the ionization correction and in vitro $\mathrm{pH} 7.0$ measurements were improved outside of confidence intervals. However, due to the limited dataset and lack of consistent prediction improvements, a general recommendation to change buffer $\mathrm{pH}$ to 7.0 cannot be made at this time. Additionally, it is not recommended to use the ionization correction with data generated at pH 7.4 as this may result in artificially adjusted predictions. Further investigations are needed to bridge the gap between in vitro and in vivo correlations and improve drug selection and dosing for patients.

\section{Authorship Contributions}

Participated in research design: Rougée, Mohutsky, Hall.

Conducted experiments: Rougée, Bedwell, Ruterbories.

Contributed new reagents or analytical tools: Rougée, Mohutsky, Bedwell, Ruterbories.
Performed data analysis: Rougée, Mohutsky, Bedwell, Ruterbories, Hall.

Wrote or contributed to the writing of the manuscript: Rougée, Mohutsky, Bedwell, Ruterbories, Hall.

\section{References}

Ahonen J, Olkkola KT, and Neuvonen PJ (1995) Effect of itraconazole and terbinafine on the pharmacokinetics and pharmacodynamics of midazolam in healthy volunteers. $\mathrm{Br} \mathrm{J} \mathrm{Clin}$ Pharmacol 40:270-272.

Austin RP, Barton P, Cockroft SL, Wenlock MC, and Riley RJ (2002) The influence of nonspecific microsomal binding on apparent intrinsic clearance, and its prediction from physicochemical properties. Drug Metab Dispos 30:1497-1503.

Backman JT, Kivistö KT, Olkkola KT, and Neuvonen PJ (1998) The area under the plasma concentration-time curve for oral midazolam is 400 -fold larger during treatment with itraconazole than with rifampicin. Eur J Clin Pharmacol 54:53-58.

Berezhkovskiy LM (2011) The corrected traditional equations for calculation of hepatic clearance that account for the difference in drug ionization in extracellular and intracellular tissue water and the corresponding corrected PBPK equation. J Pharm Sci 100:1167-1183.

Berezhkovskiy LM, Liu N, and Halladay JS (2012) Consistency of the novel equations for determination of hepatic clearance and drug time course in liver that account for the difference in drug ionization in extracellular and intracellular tissue water. J Pharm Sci 101:516-518.

Black DJ, Kunze KL, Wienkers LC, Gidal BE, Seaton TL, McDonnell ND, Evans JS, Bauwens JE, and Trager WF (1996) Warfarin-fluconazole. II. A metabolically based drug interaction: in vivo studies. Drug Metab Dispos 24:422-428.

Bornemann LD, Min BH, Crews T, Rees MM, Blumenthal HP, Colburn WA, and Patel IH (1985) Dose dependent pharmacokinetics of midazolam. Eur J Clin Pharmacol 29:91-95.

Braeckman RA, Stirtan WG, and Soni PN (2014) Phase 1 study of the effect of icosapent ethyl on warfarin pharmacokinetic and anticoagulation parameters. Clin Drug Investig 34:449-456.

Brooks HB, Geeganage S, Kahl SD, Montrose C, Sittampalam S, Smith MC, and Weidner JR (2012) Basics of Enzymatic Assays for HTS, in Assay Guidance Manual (Sittampalam GS, Coussens NP, Brimacombe K, Grossman A, Arkin M, Auld D, Austin C, Bejcek B, Glicksman $\mathrm{M}$, Inglese J, et al. eds), Eli Lilly \& Company and the National Center for Advancing Translational Sciences, Bethesda, MD.

Chen Y, Ma F, Lu T, Budha N, Jin JY, Kenny JR, Wong H, Hop CE, and Mao J (2016) Development of a physiologically based pharmacokinetic model for itraconazole pharmacokinetics and drug-drug interaction prediction. Clin Pharmacokinet 55:735-749.

Chi KN, Tolcher A, Lee P, Rosen PJ, Kollmannsberger CK, Papadopoulos KP, Patnaik A, Molina A, Jiao J, Pankras C, et al. (2013) Effect of abiraterone acetate plus prednisone on the pharmacokinetics of dextromethorphan and theophylline in patients with metastatic castrationresistant prostate cancer. Cancer Chemother Pharmacol 71:237-244.

Chiba M, Ishii Y, and Sugiyama Y (2009) Prediction of hepatic clearance in human from in vitro data for successful drug development. AAPS J 11:262-276.

Cojocaru V, Winn PJ, and Wade RC (2012) Multiple, ligand-dependent routes from the active site of cytochrome P450 2C9. Curr Drug Metab 13:143-154.

de Groot MJ, Alex AA, and Jones BC (2002) Development of a combined protein and pharmacophore model for cytochrome P450 2C9. J Med Chem 45:1983-1993.

Englund G, Lundquist P, Skogastierna C, Johansson J, Hoogstraate J, Afzelius L, Andersson TB, and Projean D (2014) Cytochrome p450 inhibitory properties of common efflux transporter inhibitors. Drug Metab Dispos 42:441-447.

Fowler S and Zhang H (2008) In vitro evaluation of reversible and irreversible cytochrome P450 inhibition: current status on methodologies and their utility for predicting drug-drug interactions. AAPS J 10:410-424.

Hall JE and Guyton AC (2015) Guyton and Hall Textbook of Medical Physiology, Elsevier Health Sciences, Philadelphia.

Heimark LD, Wienkers L, Kunze K, Gibaldi M, Eddy AC, Trager WF, O’Reilly RA, and Goulart DA (1992) The mechanism of the interaction between amiodarone and warfarin in humans. Clin Pharmacol Ther 51:398-407.

Johnson EF and Stout CD (2005) Structural diversity of human xenobiotic-metabolizing cytochrome P450 monooxygenases. Biochem Biophys Res Commun 338:331-336.

Kharasch ED, Walker A, Hoffer C, and Sheffels P (2005) Sensitivity of intravenous and oral alfentanil and pupillary miosis as minimally invasive and noninvasive probes for hepatic and first-pass CYP3A activity. J Clin Pharmacol 45:1187-1197.

Kilford PJ, Stringer R, Sohal B, Houston JB, and Galetin A (2009) Prediction of drug clearance by glucuronidation from in vitro data: use of combined cytochrome P450 and UDPglucuronosyltransferase cofactors in alamethicin-activated human liver microsomes. Drug Metab Dispos 37:82-89.

Kim JH, Johannes L, Goud B, Antony C, Lingwood CA, Daneman R, and Grinstein S (1998) Noninvasive measurement of the $\mathrm{pH}$ of the endoplasmic reticulum at rest and during calcium release. Proc Natl Acad Sci USA 95:2997-3002.

Lam YW, Alfaro CL, Ereshefsky L, and Miller M (2003) Pharmacokinetic and pharmacodynamic interactions of oral midazolam with ketoconazole, fluoxetine, fluvoxamine, and nefazodone. J Clin Pharmacol 43:1274-1282.

London JW, Shaw LM, Fetterolf D, and Garfinkel D (1975) A systematic approach to enzyme assay optimization illustrated by aminotransferase assays. Clin Chem 21:1939-1952.

Lu C, Li P, Gallegos R, Uttamsingh V, Xia CQ, Miwa GT, Balani SK, and Gan LS (2006) Comparison of intrinsic clearance in liver microsomes and hepatocytes from rats and humans: evaluation of free fraction and uptake in hepatocytes. Drug Metab Dispos 34:1600-1605.

Mateus A, Matsson P, and Artursson P (2013) Rapid measurement of intracellular unbound drug concentrations. Mol Pharm 10:2467-2478.

Miners JO and Birkett DJ (1998) Cytochrome P4502C9: an enzyme of major importance in human drug metabolism. Br J Clin Pharmacol 45:525-538.

Mohutsky M and Hall SD (2014) Irreversible enzyme inhibition kinetics and drug-drug interactions. Methods Mol Biol 1113:57-91.

Mohutsky MA, Chien JY, Ring BJ, and Wrighton SA (2006) Predictions of the in vivo clearance of drugs from rate of loss using human liver microsomes for phase I and phase II biotransformations. Pharm Res 23:654-662.

Neal JM, Kunze KL, Levy RH, O'Reilly RA, and Trager WF (2003) Kiiv, an in vivo parameter for predicting the magnitude of a drug interaction arising from competitive enzyme inhibition. Drug Metab Dispos 31:1043-1048. 
Olkkola KT, Backman JT, and Neuvonen PJ (1994) Midazolam should be avoided in patients receiving the systemic antimycotics ketoconazole or itraconazole. Clin Pharmacol Ther $\mathbf{5 5}$ $481-485$.

Olkkola KT, Ahonen J, and Neuvonen PJ (1996) The effects of the systemic antimycotics, itraconazole and fluconazole, on the pharmacokinetics and pharmacodynamics of intravenous and oral midazolam. Anesth Analg 82:511-516.

O'Reilly RA, Trager WF, Rettie AE, and Goulart DA (1987) Interaction of amiodarone with racemic warfarin and its separated enantiomorphs in humans. Clin Pharmacol Ther 42: 290-294.

Pelkonen O, Turpeinen M, Uusitalo J, Rautio A, and Raunio H (2005) Prediction of drug metabolism and interactions on the basis of in vitro investigations. Basic Clin Pharmacol Toxico 96: $167-175$.

Perry PJ, Miller DD, Arndt SV, and Cadoret RJ (1991) Clozapine and norclozapine plasma concentrations and clinical response of treatment-refractory schizophrenic patients. Am J Psychiatry 148:231-235.

Pollock AS (1984) Intracellular $\mathrm{pH}$ of hepatocytes in primary monolayer culture. Am J Physiol 246: F738-F744.

Poulin P and Haddad S (2013) Toward a new paradigm for the efficient in vitro-in vivo extrapolation of metabolic clearance in humans from hepatocyte data. J Pharm Sci 102:3239-3251.

Poulin P, Hop CE, Ho Q, Halladay JS, Haddad S, and Kenny JR (2012a) Comparative assessmen of in vitro-in vivo extrapolation methods used for predicting hepatic metabolic clearance of drugs. J Pharm Sci 101:4308-4326.

Poulin P, Kenny JR, Hop CE, and Haddad S (2012b) In vitro-in vivo extrapolation of clearance: modeling hepatic metabolic clearance of highly bound drugs and comparative assessment with existing calculation methods. $J$ Pharm Sci 101:838-851.

Rougée LR, Mohutsky MA, Bedwell DW, Ruterbories KJ, and Hall SD (2016) The impact of the hepatocyte-to-plasma $\mathrm{pH}$ gradient on the prediction of hepatic clearance and drug-drug interactions for CYP2D6 substrates. Drug Metab Dispos 44:1819-1827.
Scordo MG, Aklillu E, Yasar U, Dahl ML, Spina E, and Ingelman-Sundberg M (2001) Genetic polymorphism of cytochrome P450 2C9 in a Caucasian and a black African population. $\mathrm{Br}$ J Clin Pharmacol 52:447-450.

Shore PA, Brodie BB, and Hogben CA (1957) The gastric secretion of drugs: a pH partition hypothesis. J Pharmacol Exp Ther 119:361-369.

Strazzabosco M, Poci C, Spirlì C, Zsembery A, Granato A, Massimino ML, and Crepaldi G (1995) Intracellular $\mathrm{pH}$ regulation in Hep G2 cells: effects of epidermal growth factor, transforming growth factor-alpha, and insulinlike growth factor-II on $\mathrm{Na}+\mathrm{H}+$ exchange activity. Hepatology 22:588-597.

Wester MR, Yano JK, Schoch GA, Yang C, Griffin KJ, Stout CD, and Johnson EF (2004) The structure of human cytochrome P450 2C9 complexed with flurbiprofen at 2.0-A resolution. I Biol Chem 279:35630-35637.

Williams PA, Cosme J, Ward A, Angove HC, Matak Vinković D, and Jhoti H (2003) Crystal structure of human cytochrome P450 2C9 with bound warfarin. Nature 424:464-468.

Willis JV, Kendall MJ, Flinn RM, Thornhill DP, and Welling PG (1979) The pharmacokinetics of diclofenac sodium following intravenous and oral administration. Eur J Clin Pharmacol 16: 405-410.

Zhang D, Luo G, Ding X, and Lu C (2012) Preclinical experimental models of drug metabolism and disposition in drug discovery and development. Acta Pharm Sin B 2:549-561.

Zhou SF, Zhou ZW, Yang LP, and Cai JP (2009) Substrates, inducers, inhibitors and structureactivity relationships of human cytochrome P450 2C9 and implications in drug development Curr Med Chem 16:3480-3675.

Address correspondence to: Luc R. A. Rougée, Lilly Research Laboratories, Eli Lilly and Company, Indianapolis, IN. E-mail: Irougee@lilly.com 